NBER WORKING PAPER SERIES

\title{
WHAT IS THE RISK OF EUROPEAN SOVEREIGN DEBT DEFAULTS? FISCAL SPACE, CDS SPREADS AND MARKET PRICING OF RISK
}

\author{
Joshua Aizenman \\ Michael M. Hutchison \\ Yothin Jinjarak \\ Working Paper 17407 \\ http://www.nber.org/papers/w17407
NATIONAL BUREAU OF ECONOMIC RESEARCH
1050 Massachusetts Avenue
Cambridge, MA 02138
September 2011

We thank seminar participants at the Bank for International Settlements, Danmarks Nationalbank, the Bank of Canada, Columbia-Tsinghua international economics workshop, Chulalongkorn University (Sasin), and Association for Public Economic Theory 2011 Conference for very helpful comments. The views expressed herein are those of the authors and do not necessarily reflect the views of the National Bureau of Economic Research.

NBER working papers are circulated for discussion and comment purposes. They have not been peerreviewed or been subject to the review by the NBER Board of Directors that accompanies official NBER publications.

(C) 2011 by Joshua Aizenman, Michael M. Hutchison, and Yothin Jinjarak. All rights reserved. Short sections of text, not to exceed two paragraphs, may be quoted without explicit permission provided that full credit, including $(\odot)$ notice, is given to the source. 
What is the Risk of European Sovereign Debt Defaults? Fiscal Space, CDS Spreads and Market Pricing of Risk

Joshua Aizenman, Michael M. Hutchison, and Yothin Jinjarak

NBER Working Paper No. 17407

September 2011

JEL No. E43,F34,F36,G01,H63

\begin{abstract}
We estimate the pricing of sovereign risk for sixty countries based on fiscal space (debt/tax; deficits/tax) and other economic fundamentals over 2005-10. We measure how accurately the model predicts sovereign credit default swap (CDS) spreads, focusing in particular on the five countries in the South-West Eurozone Periphery (Greece, Ireland, Italy, Portugal, and Spain). Dynamic panel estimates of the model suggest that fiscal space and other macroeconomic factors are statistically significant and economically important determinants of market-based sovereign risk. Although the explanatory power of fiscal space measures drop during the crisis, the TED spread, trade openness, external debt and inflation play a larger role. As expectations of market volatility jumped during the crisis, the weakly concavity of creditors' payoff probably accounts for the emergence of TED spread as a key pricing factor. However, risk-pricing of the South-West Eurozone Periphery countries is not predicted accurately by the model either in-sample or out-of-sample: unpredicted high spreads are evident during global crisis period, especially in 2010 when the sovereign debt crisis swept over the periphery area. We "match" the periphery group with five middle income countries outside Europe that were closest in terms of fiscal space during the European fiscal crisis. We find that Eurozone periphery default risk is priced much higher than the "matched" countries in 2010, even allowing for differences in fundamentals. One interpretation is that the market has mispriced risk in the Eurozone periphery. An alternative interpretation is that the market is pricing not on current fundamentals but future fundamentals, expecting the periphery fiscal space to deteriorate markedly and posing a high risk of debt restructuring. Adjustment challenges of the Eurozone periphery may be perceived as economically and politically more difficult than the matched group of middle income countries because of exchange rate and monetary constraints.
\end{abstract}

Joshua Aizenman

Department of Economics; E2

1156 High St.

University of California, Santa Cruz

Santa Cruz, CA 95064

and NBER

jaizen@ucsc.edu

Michael M. Hutchison

Department of Economics

E2

University of California

Santa Cruz, CA 95064

hutch@ucsc.edu
Yothin Jinjarak

University of London

College Buildings, 534

London

UK, WC1H OXG

yothin.jinjarak@gmail.com 


\section{Introduction}

During 2000 to 2006, the OECD and most emerging markets experienced a remarkable decline in macroeconomic volatility and the price of risk. This period turned out to be the tail-end of the Great Moderation, a precursor of the turbulences leading to the global financial crisis of 2008-09, the consequent increase in risk premia, and the focus on fiscal challenges and the importance of fiscal space in navigating future economic challenges. The latter stages of the crisis, unfolding in 2010, focused attention on the heterogeneity of the Euro block, and the unique challenges facing the five SouthWest Eurozone Periphery countries, or SWEAP group (Greece, Ireland, Italy, Portugal, and Spain), in adjusting to fiscal fragility in the context of a ten-year old currency union. ${ }^{1}$

This paper investigates the pricing of risk associated with the sovereign debt crisis that escalated during 2010 in several European countries. Our objective is to determine whether the perception of relatively high sovereign default risk of the fiscally distressed Euro area countries, as seen in market pricing of credit default swap (CDS) spreads, may be explained by existing past or current fundamentals of debt and deficits relative to tax revenues - which we term de facto fiscal space - and other economic determinants. ${ }^{2}$ Our analysis allows us to address several questions. Does fiscal space help systematically explain the evolution of the market pricing of risk beyond that embedded in other macroeconomic indicators? Was risk in some markets (e.g. SWEAP) “overpriced” in

\footnotetext{
${ }^{1}$ The SWEAP acronym for these five countries is used in Buiter and Rahbari (2010). ${ }^{2}$ Our measure of fiscal space is from Aizenman and Jinjarak (2010). They propose a stock and flow measure of de facto fiscal space. The stock variable is defined as the inverse of the tax-years it would take to repay the public debt. In this paper, fiscal space is measured both as outstanding government debt and government deficits, relative to the de facto tax base. The deficits measure is the realized tax collection, averaged across several years to smooth for business cycle fluctuations.
} 
2010 judging by model predictions using the prevailing values of fiscal space other macro variables?

Our objectives for the empirical work are three-fold. Firstly, we determine whether CDS spreads (in a panel regression setting) are related to fiscal space measures and other economic determinants. Secondly, we address whether there is an identifiable dynamic pattern to CDS spreads during the crisis period. Thirdly, we investigate pricing differentials of CDS spreads in the Euro area, and the SWEAP in particular, compared to other countries. We seek to answer the question of whether Euro area and SWEAP CDS spreads follow the same pattern as the rest of the world or may they considered "mispriced" in some sense, especially during the 2010 European debt crisis.

To this end, we develop a pricing model of sovereign risk for a large number of countries (60) within and outside of Europe, before and after the global financial crisis, based on fiscal space and other economic fundamentals including the foreign interest rate, external debt, trade openness, nominal depreciation, inflation, GDP/Capita and economic growth. We use this dynamic panel model to explain CDS spreads and determine whether the market pricing of risk is comparable in the affected European countries and elsewhere in the world. By this methodology, and using in-sample and outof-sample predictions, we can determine whether there are systematically large prediction errors for the CDS spreads during the global financial crisis and in 2010 when the sovereign debt crisis in Europe intensified. Systematically large prediction errors may be due to mispricing of risk or may be attributable to expectations of a future decline in fundamentals that lead to higher default risk. We also "match," on the basis of similar fiscal space, each SWEAP country with a corresponding Middle Income country. This 
provides additional information on the market pricing of risk between SWEAP and countries with similar fiscal conditions but, unlike SWEAP, with histories of debt restructuring.

Our investigation reveals a complex and time-varying environment in the market for sovereign default risk. Specifically, we find empirically a key role of fiscal space in pricing sovereign risk, controlling for other relevant macro variables. The link is economically and statistically strong, and robust to the time dimension of the CDS premium, sample period, included control variables and estimation technique. We find that risk of default in the SWEAP group appeared to be somewhat "underpriced" relative to international norms in the period prior to the global financial crisis and substantially “overpriced” countries during and after the crisis, especially in 2010, with actual CDS values much higher than the model would predict given fundamentals. In addition, compared to the matched group, controlling for fiscal space and macroeconomic conditions, all of the SWEAP countries have much higher default risk assessments measured by CDS premiums.

The next section discusses the data. The third section provides a preliminary statistical analysis. The fourth section presents the empirical results. We close the paper with a discussion on possible interpretation of the emerging SWEAP risk premia, including the handicapping effect of being a member of a currency union, which reduces the country's scope of adjustment via exchange rate and monetary policy.

\section{CDS Spreads as a Measure of Sovereign Default Risk}

2.1 CDS Spreads on Sovereign Bonds 
We measure the market perception of sovereign default risk by the spreads on sovereign credit default swaps (CDS) at various maturities (tenors). ${ }^{3}$ CDS instruments are mainly transacted in over-the-counter (OTC) derivative markets. The spreads represent the quarterly payments that must be paid by the buyer of CDS to the seller for the contingent claim in the case of a credit event, in this case non-payment (or forced restructuring) of sovereign debt, and is therefore an excellent proxy for market-based default risk pricing. ${ }^{4}$ The total CDS market grew from about 10 trillion USD in 2004, when statistics were first systematically reported, to a peak prior to the global financial crisis of almost 60 trillion USD in mid-2008, and then fell sharply. The estimated gross (net) notional amount of sovereign CDS outstanding was 2,447 (233) billion USD in 2010, compared to about 2,196 billion USD in government-issued international debt securities (BIS, 2010). Figure 1 shows the outstanding notional amounts of CDS instruments on sovereign bonds across countries in late February 2011. Italy has the largest outstanding CDS notional amounts, at almost USD 300 billion, followed by Brazil, Spain and Turkey with notional amounts outstanding of over USD 150 billion.

\footnotetext{
${ }^{3}$ See Packer and Suthiphongchai (2003) and Fontana and Scheicher (2010) for discussions of sovereign CDS markets.

${ }^{4}$ An alternative proxy for default risk is the interest rate spread of sovereign debt. From an empirical standpoint, there are three main advantages of using CDS spreads rather than interest rate spreads. Firstly, CDS statistics provide timelier market-based pricing with larger coverage of industrial and developing countries than sources for national bond market rates. Secondly, using CDS spreads avoids the difficulty in dealing with time to maturity as in the case of using interest rate spreads (of which the zero yields would be preferred). Recent estimates from the Bank for International Settlements suggest that the average original and the remaining maturities of government debt instruments vary markedly across countries (BIS, 2010). Thirdly, interest rate spreads embed inflation expectations and demand/supply for credit conditions as well as default risk. We are only interested in default risk.
} 
Sovereign CDS provide a market-based real time indicator of sovereign credit quality and default risk. We consider sovereign CDS spreads at several maturities-three, five and ten-year maturities, across industrial countries and emerging markets. Despite the low probability of a credit event in most advanced economies, CDS markets are still active in most markets as buyers can use the sovereign CDS as a hedge and for mark-tomarket response. ${ }^{5}$ Buyers of the sovereign CDS may or may not own the underlying government bonds. The latter case is termed 'naked' sovereign CDS, and frequently labeled as a speculation.

CDS prices in our study are taken from CMA Datavision, a platform that is based on quotes collected from a consortium of over thirty independent swap market participants. CMA aggregates the most recent quotes and delivers the data intraday. The quoting convention for CDSs is the annual premium payment as a percentage of the notional amount of the reference obligation. The sovereign CDS spreads are reported in basis points, with a basis point equals to $\$ 1,000$ to insure $\$ 10$ million of debt. ${ }^{6}$ CDS spreads are London closing values. While CMA is not the sole provider of CDS prices, Mayordomo et al. (2010) find that, in a comparison of six major providers, CMA quotes are most consistent with a price discovery process. The majority of sovereign CDS in the market are denominated in the US dollar; in our sample, about one-third of the CDS is Euro-denominated. The CMA data set provides a broad coverage of CDS pricing over countries and years.

\footnotetext{
${ }^{5}$ Sovereign CDS can also be used to supplement corporate CDS to hedge for country risk.

${ }^{6}$ For example, if the spread is 197 basis points, meaning 197,000 USD to insure against $10,000,000$ in sovereign debt for 10 years; $1.97 \%$ of notional amount needs to be paid each year, so $0.0197 \times 10$ million $=\$ 197,000$ per year.
} 
Appendix A provides data sources and Appendix B a list of countries in the entire sample, the subset of countries included in the empirical estimation, and means of 3, 5 and10-year CDS spreads (in basis points), fiscal space and other macroeconomic indicators during the sample (2005-10).

\subsection{Empirical Studies on CDS Spreads}

Empirical studies of CDS (corporate and sovereign) are relatively new and usually deal with market microstructure issues. Our study, by contrast, is in line with the macro/international finance literature which considers macroeconomic determinants of country risk assessments and financial crises.

Several findings are particularly relevant to our analysis. As noted by Packer and Suthiphongchai (2003) and others, the CDS premium should in principle be approximately equal to the credit spread of the reference bond of the same maturity under certain conditions. However, Fontana and Scheicher (2010) demonstrate that the "basis", i.e. difference between CDS spreads and the spreads on the underlying government bonds, was not zero in Eurozone CDS markets during late 2010. They suggest that sizable deviations are attributable to limits to arbitrage and slow moving capital. Secondly, at high frequency (intraday), differences in credit quality (measured by CDS prices) are found to explain sovereign yield spreads of the Euro area governments (Beber, Brandt, and Kavajecz, 2009). ${ }^{7}$ Fontana and Scheicher (2010) argue that high CDS premium in late 2010 during the Eurozone debt crisis may be partly attributable to a

\footnotetext{
${ }^{7}$ Beber et al. study microstructure data of bond quotes and transactions from the interdealer markets, covering Austria, Belgium, Finland, France Germany Greece, Italy, Netherlands, Portugal and Spain. Their sample period is April 2003 to December 2004. 
decline in the appetite for credit-risky instruments and falling market liquidity rather than entirely due concerns about principle losses on outstanding sovereign debt. In addition, empirical research finds that daily sovereign interest spreads are more likely to lead sovereign CDS spreads in emerging markets (Ammer and Cai, 2007). ${ }^{8}$ Taken together, both studies suggest that sovereign interest rates and CDS spreads have common underlying causes, rather than one driving the other.

There is evidence that CDS spreads may be driven by macro economic conditions. Amato (2005) decomposes CDS spreads into risk premium and risk aversion and finds that both are influenced by macroeconomic conditions. Packer and Zhu (2005) find that contractual terms influence CDS spreads, but that significant "regional effects" (differential pricing across regions) is also evident. Micu et al. (2006) also find that credit rating announcements have a large influence on CDS spreads. In explaining recent developments, Berndt and Obreja (2010) suggest that “economic catastrophe risk” rose sharply in 2007-08 pushing up CDS spreads. Cecchetti et al. (2010) plot several fiscal indicators against CDS spreads for advanced economies. They find correlations across countries with substantial heterogeneity. ${ }^{9}$ Longstaff et al. (2011) study sovereign CDS of several emerging markets from October 2000 to January 2010. They found that the sovereign spreads are more associated with global factors (US stock, treasury, and high

\footnotetext{
${ }^{8}$ Ammer and Cai examine daily data from February 2001 to March 2005, covering Brazil, China, Colombia, Mexico, Philippines, Turkey, and Uruguay. On interest rates, CDS spreads, and speculation, see also the discussion of findings from the European Commission (Tait and Oakley, 2010), which suggests no strong causality between the two.

${ }^{9}$ For example, they plot the forecast level of general government debt/GDP against January 2010 CDS spreads for 21 advanced economies and find a positive correlation.
} 
yield markets) than local factors (stock return, exchange rate, and foreign reserve).

Dooley and Hutchison (2009) find that financial, economic and regulatory "news" emanating from the U.S. during the global financial crisis quickly impacted sovereign CDS spreads in emerging markets.

\section{Statistical Contours}

Monthly 5-year CDS spreads from 2005-2011 are plotted for the SWEAP and other selected countries (countries which are matched with the SWEAP group, discussed below) in Figure 2. Judging by these spreads, financial stress in global markets emerged in early 2008 but became dramatic and widespread in late 2008. The turbulence subsided by mid-2009 in most countries, with the notable exception of the SWEAP group: Greece, Ireland, Italy, Portugal, and Spain. For Greece, the unraveling of its fiscal condition in late 2009 resulted in a manifold increase in sovereign CDS spreads. For Ireland, the sovereign CDS spreads have widen sharply twice, in early 2009 and in late 2010. By 2010, spreads of the SWEAP group were already much higher than those of most emerging market countries (e.g. above the spreads of South Africa, Mexico, Panama, Malaysia and Colombia in Figure 2). On the other hand, sovereign spreads of Germany and the US remained very low throughout the period (not shown).

Table 1 reports the annual mean values (standard deviation in parentheses) of sovereign CDS spreads (5-year tenor), fiscal space and macroeconomic fundamentals for SWEAP and other country groupings. The table shows average values for the period before crisis (2005-07) and during the crisis (2008-10 and individual years). The fall of 
2008 was the height of the global financial crisis, while the latter part of 2009 was a recovery period as financial panic and the liquidity crisis subsided for most countries. However, the SWEAP sovereign debt crisis manifested mainly in 2010 and later. Prior to the crisis, SWEAP CDS values were quite low, ranging from 8-17 basis points on average, which are somewhat but not markedly higher than the mean of other Euro countries (11 basis points) and lower than the non-Euro OECD group (35 basis points). During the early months into the global financial crisis, 2008-09, sovereign CDS spreads rose in virtually every country. However, spreads dropped very substantially in all regions by 2010 except for the Euro area excluding SWEAP, where it remained roughly unchanged, and SWEAP, where it rose dramatically. SWEAP CDS average values in 2010 ranged from 238 basis points in Italy to 1027 basis points in Greece. By contrast, in 2010, OECD countries (non-Euro members) had an average CDS spread of 118 basis points and non-SWEAP Euro members had an average spread of 101 basis points.

As our main objective is to investigate the link between fiscal space and the pricing of default risk, we also track the adjustment of fiscal capacity across countries. Table 1 shows the fiscal balance to tax base ratio and the public debt to tax base ratio. OECD (excluding the Euro countries) and non-SWEAP Euro countries experienced an increase in debt/tax ratios by 0.2 percent and 0.3 percent, respectively, between 2005-07 and 2010. For Ireland and Greece, the deterioration in fiscal circumstances was much more drastic: the government debt of Ireland climbed from 25\% of GDP in 2007 to almost $100 \%$ of GDP in 2010, while the government debt of Greece grew from 95\% to over $140 \%$. As a result, the debt/tax ratio of Ireland jumped from 0.9 to 3.2 and that of Greece from 3.2 to 4.5, leaving both countries with a much less room for a flexible policy 
response on the fiscal side. The large increase of debt/tax ratios in both countries captures a high degree of distress in their economic fundamentals, including the government assumption of banking sector liabilities in the case of Ireland. Similarly large deteriorations in fiscal space for these countries are also evident in the fall in fiscal balance to tax ratios.

We illustrate further the 2005-07 fiscal preconditions, as measured by debt/tax (and debt/gdp) and deficit/tax (deficit/gdp), in the two panels of Figure 3 by country group. Lower pre-crisis government debt and lower fiscal deficits relative to the tax base imply greater fiscal capacity. The figure shows that fiscal space was weakest (highest levels of debt and deficits relative to the tax base) in the middle-income countries, although the average debt to gdp ratio was lower than the other groups. This reflects generally lower tax bases in the middle income countries. Generally, the SWEAP had more limited fiscal space during the tranquil period than other high-income groups higher average debt and deficits to the relative to the tax base (despite a significant budget surplus in Ireland during this period), and a higher level of debt to GDP.

\section{Methodology and Empirical Results}

\subsection{Methodology}

The dependent variables in our formal empirical work are sovereign CDS spreads of 5 year maturity (regressions with 3 and 10-year maturities are shown in the appendix table), ${ }^{10}$ estimated in a panel regression, $y_{i t}=\alpha_{i}+\lambda_{t}+\theta \Delta y_{i t-1}+\mathrm{X}_{i t}^{\prime} \beta+\varepsilon_{i t}$; where $y$ is the

\footnotetext{
${ }^{10}$ Our CDS data set contains 1-10 year maturities. We focus on the 5-year maturity since this is the deepest and most actively traded CDS market. While there is no precise
} 
CDS spread, $i$ stands for country and $t$ for year; $\mathrm{X}$ is a vector of controls. The sample covers a panel of 60 countries from 2005-10. The vector X includes fiscal space (government debt/tax and fiscal deficit/tax)— the focus of our work—as well as several other variables that frequently employed in the literature to explain country risk. These variables are the TED spread, external debt (total foreign liabilities/GDP), trade openness (trade/GDP) and inflation.

As the conditions for consistent estimation in the dynamic panel are known to be demanding, our solution is to work with both a simple fixed-effects model and other estimation specifications, including clustered standard errors and the Arellano-Bond dynamic panel estimator. Arellano-Bond is a GMM estimator with a instruments (exogenous and lagged values), well suited to the problem at hand, with a substantially larger number of cross-section units (50 countries), but requires many period of data as the instruments to account for the correlation of lagged dependent variable and the unobserved error terms. We consider fixed effects, clustered standard errors, and GMM in several variants of the model as bounding the causal effects of interest. The sovereign spreads are estimated in level. We also consider for GMM the dependent variable in log multiplied by a hundred, allowing the coefficients to be interpreted in terms of a percentage change of sovereign default risks (this terminology also aligns with standard practice in the financial sector that discusses the percentage change of CDS spreads).

international account of government debt maturity, recent statistics suggest that the average original maturity of central government debts is around 10 years for both emerging markets and industrial countries (BIS, 2010). Hence, we also report results for 10 -year maturities in the appendix, as well as 3-year maturities for a robustness test. 


\subsection{Dynamics of CDS Spreads and Euro/SWEAP Pricing Differentials}

Table 2 considers the dynamics and structure of CDS pricing over the 2005-10 sample period. Differential pricing for the SWEAP and other Eurozone countries (nonSWEAP) is investigated. To focus on CDS pricing dynamics during the global and European financial turmoil, we include time dummy variables ( $t 2008-t 2010)$ for three crisis years: 2008 is identified as the central part of the global financial crisis, 2009 is identified as a partial recovery period, and 2010 is identified with the SWEAP debt crisis and post-global financial crisis. We also include interaction terms between the three time dummy variables and the SWEAP countries (dummy variables denoting a SWEAP country) and between the three dummy variables and the non-SWEAP Euro countries.

In all of the CDS spread regressions, the fiscal space measure (higher value is equivalent to lower fiscal capacity) is positive and statistically significant at the 1 percent level - higher levels of sovereign debt and fiscal positions (deficit or debt) relative to the tax base significantly increase market pricing of sovereign default risk. Specifically, a percentage point rise in the debt/tax ratio is estimated to increase the 5-year CDS spread by between 15-81 basis points, while a one percentage point rise in the fiscal balance to tax base ratio is estimated to lower the spread by 194-829 basis points. The wide variation in the estimates, all highly statistically significant, varies with the specific estimation methodology—-the low estimates are associated with estimation with clustered standard errors and the high estimates associated with fixed effects estimation. Of the control variables, only inflation is systematically and robustly correlated with CDS spreads (higher inflation leads to higher spreads). Appendix C.1 and C.2 provide the 
robustness checks, supporting the effect of fiscal conditions on sovereign spreads in different econometric specifications. ${ }^{11}$

All of the coefficients on the 2008-10 year dummy variables are economically large and statistically significant. Controlling for other factors, sovereign spreads in 2008 were 295-349 points higher than average rates over the 2005-10 period for full sample of countries. Spreads were much lower in 2009, by some estimates somewhat lower than sample average spreads, but rose somewhat on average in 2010. For the full sample, the financial crisis impact on CDS spreads was concentrated in 2008.

For Euro countries, including the SWEAP group, sovereign spreads were substantially less than the international average in 2008. SWEAP CDS were spreads were 159-249 points lower than average spreads prevailing in 2008. SWEAP spreads were somewhat above the average in 2009 and then rose sharply in 2010, recording levels 174324 points above average. It is evident that sovereign default risk in the SWEAP was differentially priced much higher than the average of other countries, and moved in the opposite direction of the international trend in 2010. Risk assessments were falling around most of the world in 2010 but rising sharply in the SWEAP group.

\footnotetext{
${ }^{11}$ For GMM estimation, the test statistics (p-values reported) indicate that these dynamic panel regressions perform well on the whole sample. The Sargan test of over-identifying restrictions has a null hypothesis of exogenous instruments; in all cases, corresponding pvalues of the Sargan test cannot reject the null. The AR(1) test has a null of no autocorrelation in first differences and the AR(2) test has a null of no autocorrelation in levels; in most cases, the test cannot reject that average autocovariance in residuals of order 1 [AR(1)] is 0 , whereas the results from AR(2) test are inconclusive (given that time dimension of the panels in GMM is constrained to 6 at most, 2005-10, subject to the construction of the lagged instrument values). The Sargan test provides some level of confidence that the residuals are uncorrelated with a group of explanatory variables.
} 


\subsection{CDS Spreads, Fundamentals and Structural Change}

The focus on dynamics highlight how SWEAP experienced much higher CDS spreads than most of the world in 2010, even controlling for their deteriorating fiscal situation and other factors. Table 3 considers stability issues by estimating the model over the full balanced sample, 2005-10 (columns 1-4), pre-crisis sample (2005-07, columns 58) and crisis sample (2008-10, columns 9-12). The sub-samples are symmetric by including the same set of countries over a period of three years. The same set of control variables is also included in these regressions, with a focus on fiscal space, but the time dummies and interactive terms are excluded.

The estimates for the full sample in Table 3 are included for comparison with the results in Table 2 which include time dummies and interactive terms. The results, not surprisingly, are very similar. However, important differences are evident in the estimates from the two sub-samples. In particular, all of the fiscal space estimates are highly statistically and economically important in the pre-crisis "tranquil" 2005-07 sample, shown in columns 5-8. Debt and deficits relative to the tax base clearly lead to much higher risk assessments and CDS spreads.

As noted, a structural break appears to have occurred during the turbulent 200810 crisis episode, shown in columns 9-12. During the crisis, pricing of risk is largely decoupled from our two fiscal space measures. The ability of the model to explain CDS spreads drops from around $70-80 \%$ in the tranquil period to $45-60 \%$ during the crisis. Although explanatory power of fiscal space measures drop during the crisis, the TED spread, trade openness, external debt and inflation play a larger role. Given turbulent conditions during the crisis period, markets apparently did not focus on current fiscal 
fundamentals. One interpretation is that the markets simply overreacted and mispriced risk of default. Another interpretation is that markets may have emphasized more on expectations of future deterioration in fiscal space that were not fully reflected in current economic conditions. ${ }^{12}$ The emergence of the TED spread as a key pricing factor in the crisis also suggests that expectations of market volatility jumped during the crisis and that this pushed up CDS spreads. In particular, possible default implies that the payoff to creditors is weakly concave (fixed payoff in good times, declining with an adverse shock above a threshold in bad times), suggesting that higher volatility will reduce the expected payoff in countries exposed to higher volatility during a crisis for a given debt/tax or debt/gdp and thereby increasing CDS spreads. ${ }^{13}$ This also explains the impact of the end of the Great Moderation—countries with greater exposure to volatility, other things equal, are facing higher spreads.

\subsection{SWEAP and the Euro-Area CDS Pricing Before and During the Crisis}

\footnotetext{
${ }^{12}$ We also investigated whether the pricing of CDS spreads amongst the SWEAP and the non-SWEAP Euro countries (Euro-SWEAP) respond differently to fundamentals than the rest of world when the full set of fundamental explanatory variables is included. We estimated the model over 2005-10, reflecting the full sample and consisting of both the tranquil and turbulent periods. We focused on 10-year CDS spreads and considered interaction terms of SWEAP and Euro-SWEAP with all of the fundamental variables. The point estimates of interaction terms on government debt/tax suggest that the nonSWEAP Euro area countries have much narrower spreads than the sample average and the SWEAP area have much larger spreads. However, these differences are not statistically significant. The same result holds for the other fundamental factors. One exception is the trade openness variable: on average, trade openness is positively associated with CDS spreads, but less than average for non-SWEAP Euro area and more than average for SWEAP. We omit these results for brevity. They are available upon request.

${ }^{13}$ A related point is made by Aizenman and Marion (2002).
} 
In order to determine how the balanced sample (2005-10) and pre-crisis sample (2005-07) models of Table 3 predict for various country groups and the SWEAP countries, we report the in-sample and out-of-sample prediction errors over various years in Table 4. Our objective is to determine whether prediction errors demonstrate a discernable pattern. The in-sample prediction errors are estimated from the full sample model estimates reported in column 3 of Table 3 and the out-of-sample errors are estimated from the pre-crisis sample estimates reported in column 9 of Table 3.

For exposition purposes, we calculate the prediction errors in Table 4 as a ratio of the actual relative to the predicted CDS spreads as:

$$
\text { Prediction Error }=\frac{y_{i t}}{y_{i t}^{p}}=\frac{\text { Actual } 5-y r . C D S \text { Spread }}{\text { Predicted } 5-\text { year CDS Spread }}
$$

Hence, if the prediction error is greater than 1 , we have a case of under-prediction which provides supportive evidence that the CDS is over-priced. Table 4 reports the prediction errors by individual SWEAP countries and country grouping for the 2008-10 and a breakdown for years 2008, 2009 and 2010.

The table shows that in-sample and out-of-sample prediction errors were very substantial across countries and country-groups during the crisis period, with out-ofsample errors particularly large. Average errors over 2008-10, for example, indicate that actual CDS spreads exceeded out-of-sample forecast spreads with multiples ranging from 2.3 (Middle Income countries) to 12.9 (non-Euro OECD). Under predictions of CDS spreads of this magnitude are extraordinary. Under predictions (out-of-sample) for the SWEAP countries are not particularly high in relative terms, ranging from 2.6 (Italy) to 5.3 (Ireland). 
However, the pattern across years of the crisis sample shows a divergence between the SWEAP and other country groups. In particular, the SWEAP prediction errors were relatively low in 2008 but climbed marked in 2010 compared to other regions (except the non-SWEAP Euro area). The financial crisis that emerged in 2008 struck the OECD (non-Euro) area particularly hard, with very high out-of-sample prediction errors (31.6). These errors were only 1.6 in 2009, and climbed to 5.4 in 2010. By contrast, the SWEAP area did not experience such dramatic prediction errors in 2008 but these errors rose marked in 2009 and especially 2010. Perhaps reflecting some contagious effect, the Euro area (excluding SWEAP), also experience a dramatic climb in prediction errors in 2010 — much larger than the SWEAP group.

\subsection{Preconditions: Fiscal Positions Prior to the Financial Crisis}

Figure 3 suggests that, in the run up to the global financial crisis, fiscal positions in the Euro area were relatively strong, and the SWEAP area roughly in line with other OECD countries. The figure shows the fiscal balance and public debt positions by country group--middle income, high income (non-OECD), SWEAP, OECD (non-Euro area) and the Euro area (non-SWEAP) -- before the global financial crisis: the 2005-07 average for fiscal balance to GDP and fiscal balance to tax base in the first part of the figure, and the 2005-07 average public debt to GDP and public debt to tax base ratio in the second part of the figure.

Fiscal conditions in Euro countries less the SWEAP were in line with other countries prior to the global financial crisis. The average debt/tax ratio (1.38) was lower than the average of other OECD countries (1.66). The Euro area debt/GDP (55\%) was 
slightly higher than other OECD countries (51\%). The SWEAP group had a somewhat worse fiscal position, but not markedly so, with an average debt/tax ratio of 1.94 over the period, somewhat above the non-Euro OECD group average (1.66). This is much less than the average for the middle income group (2.75). However, the SWEAP debt to GDP ratio was higher than the other groups at an average $68 \%$ over the period running up to the financial crisis. A similar pattern is seen for fiscal balance measures, shown in the second part of Figure 3.

Are fiscal conditions prior to the crisis linked to market responses during the crisis episode? To recall, in the years leading to the Euro, prominent US economists were skeptical about the Euro project, raising questions about the logic of monetary unification without deep fiscal unification. Arguably, the first ten years of the Euro, celebrated in 2008, were taken by the market and key observers as an illustration that the earlier fiscal concerns were overblown. This view was supported by the remarkable switch of the initial depreciation of the Euro against the US dollar, into a solid appreciation. In his Keynote at Frankfurt am Main 30 May 2008, “The Eurosystem and its Prospects - History in the Making” Professor Axel Weber, President of the Deutsche Bundesbank, noted

"In 1998, however, the kick-off of the Eurosystem was regarded not only with curiosity and optimism, but also with concern and skepticism. On the one hand, pessimists predicted that the euro would be short-lived. They did not want to part with their respective national currencies, which - as in the case of the D-Mark - had often evolved into a symbol of national identity. On the other hand, the euro's proponents believed that the single currency would become a major catalyst for structural reform, thereby significantly boosting economic growth in the euro area. Today, with the benefit of hindsight, we know that neither excessive pessimism nor exuberant optimism was justified. Nonetheless, the Eurosystem has delivered a remarkable performance over its first decade." 
"Now, what are the determinants of the Eurosystem's success? Why did a currency area with no track record of its own attain such a high degree of credibility in so short a time? As I have already indicated, the bulk of confidence in the fledgling European single currency was generated by the Eurosystem's institutional framework, which encompasses its independence, its mandate and its monetary policy strategy, plus an institutional framework geared at commanding the support of equally stability-oriented fiscal policies, as embedded in the Stability and Growth Pact (SGP). Key elements of this institutional framework have been transferred to the Eurosystem from the national central banks (NCBs), including the Deutsche Bundesbank. Consequently, with the transfer of parts of the NCBs' structure and ethos, the reputation of the currencies that were stable prior to EMU has lived on in the euro."

With the benefit of hindsight, in the years prior to the 2008-9 crisis hitting SWEAP, the market may have underestimated the fiscal challenges facing the Euro block, believing that Weber's position "with the transfer of parts of the national central banks' structure and ethos, the reputation of the currencies that were stable prior to EMU has lived on in the euro." was accurate.

Has the SWEAP crisis has been a wake-up call regarding the fiscal vulnerabilities of the Euro Zone? Figure 4 shows a scatter plot of government fiscal space in 2005-07 prior to the financial crisis against 2008-10 prediction errors in Euro and non-Euro zone countries (using equations 6 and 8 from Table 3). The left panels show the debt/tax revenue measure and the right panels show the deficit/tax revenue fiscal space measure. The correlation in the Euro zone (non-Euro area) between government debt/tax revenues and prediction error is -.72 (-.28). And the correlation in the Euro zone (non-Euro area) between fiscal balances to tax revenues and prediction error is .59 (.09) for other (non Euro) countries in the sample. Euro area countries with high debt and deficits (surpluses) during the pre-crisis period experienced lower (higher) CDS spreads (relative to predicted values) than did the non-Euro area countries. 
Overall, these data do not support the argument that the market was particularly sanguine about Euro area sovereign risk during the tranquil period and that this led to an over-reaction (over pricing risk) during the crisis period. CDS spreads relative to out-ofsample predicted values in the SWEAP group are high, but not out of line with other country groups. Moreover, there is no evidence that debt and deficits in the SWEAP countries prior to the crisis led to high prediction errors during the crisis.

\subsection{SWEAP Compared to "Matched" Middle Income Countries}

To gain further insight, we "match" the SWEAP countries with 5 middle-income countries (MI) that in 2010, at the peak of the European crisis, were closest in terms of fiscal space (2010 debt/tax). The objective is to see if the pricing of risk in the SWEAP was different than corresponding MI countries. The matches (SWEAP to MI), shown in Table 5, are Spain - South Africa, Greece - Panama, Ireland - Malaysia, Italy - Mexico and Portugal - Colombia. These countries had similar debt to tax base ratios in 2010. The question is whether they had other similar economic characteristics, especially the price of sovereign default risk.

Figure 5 shows a cluster diagram of the prediction errors during these two periods, depicting the size of debt/tax by circles. The prediction errors are based on the in-sample prediction errors from equations 2 and 4 in Table 3. The circle size is proportional to the 2005-07 pre-crisis public debt to tax base ratio. There is a negative correlation (-0.62) between 2005-07 pre-crisis and 2008-10 crisis prediction errors, i.e. large (small) prediction errors in the tranquil period tend to be followed by small (large) prediction errors in the crisis period. However, there is a wide asymmetry between the 
clusters of errors of the SWEAP and the clusters of errors of their matched MI countries. In particular, the relatively small prediction errors of the SWEAP countries in the precrisis period are followed by quite large prediction errors in the crisis period. By contrast, little relation is seen in the error clusters of the MI countries - a wide variation among the prediction errors in this group in the pre-crisis period is not seen in the crisis period, during which time all of the matched MI country predictions were quite close to realized CDS spreads.

The data in Figure 5 suggest that sovereign risk in SWEAP countries is overpriced in comparison with corresponding MI countries. Pursuing this further, Table 5 summarizes in more detail the characteristics of the SWEAP with the matched countries. The table shows, before and during the crisis, the evolution of CDS spreads, fiscal space, the tax base, inflation, currency depreciation, inflation external debt, foreign reserves, trade openness and real GDP growth.

This table allows a detailed comparison of the matched countries. In terms of initial conditions, for example, Italy and Mexico had very similar debt/tax ratios in 200507 (2.2-2.5), but Mexico had much higher borrowing costs and sovereign CDS premium which were more than four times higher than Italy (57 points versus 13 points). Differential borrowing costs, however, were consistent with a weaker currency and higher inflation rates in Mexico. The difference in CDS spreads between the two countries at this time appears is in line with relative fiscal space-similar debt and deficit positions-- and economic performance. By 2010, however, the roles were reversed: Italy had a CDS spread of 238 and Mexico 113, despite still having very similar debt/tax and deficit/tax ratios and Mexico maintaining higher rates of inflation. Pessimism about 
Europe in 2010 appears to have led to higher risk perceptions in Italy compared to Mexico than would be justified by fundamentals. This observation is seen as well in Figure 5, where the prediction errors for 2008-10 averaged about 1.0 in Mexico and 2.6 in Italy. (It should be noted, however, that real GDP growth was stronger in Mexico than Italy at this time, and its currency stronger. So not all fundamentals pointed to more equal CDS spreads).

Another illustrative case is Spain and South Africa. The 2005-07 (debt/tax) ratios were very similar, but South Africa was subject to higher government borrowing costs and had a substantially higher CDS spread (53 points versus 17 points). Partly this reflected the respective political situations but also that South Africa had higher inflation and a higher rate of currency depreciation. Again, the market pricing of risk was reversed in the two countries by 2010 with the CDS spread in Spain averaging 348 points compared to 124 in South Africa. This difference may be partly due to fundamentalsreal GDP growth was higher and the debt/tax ratio lower in South Africa. On the other hand, the inflation rate in South Africa was almost 6\% in 2010, compared to less than 3\% in Spain. The suspicion that default risk in Spain is mispriced compared to South Africa is also suggested by the prediction error given in Figure 5-the average CDS spread to predicted spread for Spain during 2008-10 is almost 4 but about 1 in South Africa, where the later indicates no under- or over-pricing.

On the other hand, Table 5 also shows that SWEAP had lower foreign reserves than the matched MI countries. Given the Euro status of SWEAP, however, it is uncertain what would be the role of the reserves (compared to a precautionary rationale for reserves hoarding of the emerging markets). Nonetheless, in all cases SWEAP countries had 
larger external debt (\%GDP) and the government bond markets that performed worse in 2010 than the matched MI countries.

In summary, there is strong evidence that high market default risk assessments in the SWEAP are partly attributable to deteriorating fundamentals but that a large component is unpredicted. Actual CDS spreads in the SWEAP much higher than what the model predicts, given the actual realization of fundamentals. In terms of the model, these spreads may be "mispriced" due to excessive pessimism on the part of market participants about the SWEAP or expectations of the further deterioration of fundamentals. This point is well illustrated by a comparison of SWEAP with MI countries with similar fiscal conditions. In every case, risk pricing of the SWEAP is comparatively high given current economic conditions. However, a comparison with other country groupings, outside of the Middle Income countries, provides less support for relative over-pricing of risk in SWEAP. In particular, other OECD countries (outside of the Euro zone) and non-SWEAP Euro zone countries have also experienced very high CDS premiums—-much higher than model predictions—during the crisis period.

\section{Conclusion}

We develop a model of pricing of sovereign risk for a large number of countries within and outside of Europe, before and after the global financial crisis, based on fiscal space and other economic fundamentals. We use this model to explain CDS spreads and determine whether the market pricing of risk is comparable in the affected European countries and elsewhere in the world. By this methodology and using out-of-sample predictions, we determine whether there are systematically large prediction errors for the 
CDS spreads during the global financial crisis period 2008-10 and especially 2010 when the sovereign debt crisis in Europe surfaced.

We find that market-priced risk of sovereign debt as measured by CDS spreads is partly explained by fiscal space and other economic determinants. Fiscal space is an economically important and robust predictor of CDS spreads using a data set of more than fifty countries over 2005-10, measured either by government debt/tax base or government deficits/tax base. In addition to validating that fiscal space is an important determinant of market-based sovereign risk, we find evidence of mispricing in SWEAP given current fiscal space and other current fundamentals: unpredicted low CDS in tranquil period and unpredicted high during global crisis period, especially 2010 when sovereign debt crisis swept over Euro area. We also matched the SWEAP with 5 middleincome countries outside Europe that were closest in terms of fiscal space (debt/tax) during the crisis period. We find that SWEAP default risk is priced much higher than the "matched" countries in 2010, even allowing for differentials in fiscal space and other fundamentals.

On the other hand, outside of the Middle Income countries, several country groups experienced similarly "mispriced” CDS spreads during the crisis period, though the dynamics are different than with SWEAP. Other OECD countries tended to have very high prediction errors—-high CDS spreads compared with model predictions—during the first year of the international financial and liquidity crisis (2008), while SWEAP experienced very substantial prediction errors in 2010 when the sovereign debt crisis initially swept over Europe. 
One interpretation of these findings is that market-priced risk of sovereign default follows waves of contagion, overreacting and mispricing risk of sovereign default over a period of several years. The extraordinarily high CDS spreads in SWEAP in 2010, largely unpredicted by the model, may be attributable to excessive pessimism and an overreaction to the fiscal deterioration. Another interpretation, of course, is that the CDS market is pricing default risk not primarily on current fundamentals but future fundamentals, expecting the SWEAP fiscal space to deteriorate markedly. The adjustment challenges of the SWEAP may be viewed as economically and politically more difficult due to exchange rate inflexibility associated with participation in the Euro area that is not a constraint in the matched group of the middle income countries. 


\section{References}

Aizenman, Joshua, and Yothin Jinjarak. 2010. “De facto Fiscal Space and Fiscal Stimulus.” NBER No. 16539, November.

Aizenman, Joshua and Nancy Marion. 2002. "Reserve Uncertainty and the Supply of International Credit,” Journal of Money Credit and Banking, 34(3), (August, Part 1).

Amato, Jeffry D. 2005 “Risk Aversion and Risk Premia in the CDS Market”, BIS Quarterly Review, Part 5 (December), 55-68.

Ammer, John, and Fang Cai. 2007. "Sovereign CDS and Bond Pricing Dynamics in Emerging Markets.” Board of Governors of the Federal Reserve System, December.

Bank for International Settlements. 2010. BIS Quarterly Review, OTC Derivatives Statistics. December.

Beber, Alessandro, Michael W. Brandt, and Kenneth A. Kavajecz. 2009. "Flight-to-Quality or Flight-to-Liquidity? Evidence from the Euro-area bond market.” Review of Financial Studies 22, 925-957.

Berndt, Antje and Iulian Obreja. 2010. "Decomposing European CDS Returns," Review of Finance. 14: 189-233.

Buiter, Willem and Ebrahim Rahbari. 2010. “Greece and the fiscal crisis in the Eurozone.” Centre for Economic Policy Research Policy Insight No. 51 (October).

Buiter, Willem. 2010. Global Economists View, "Sovereign Debt Problems in Advanced Industrial Countries.” CITI Economics, April 26.

Cecchetti, Stephan, M S Mohanty and Fabrizio Zampolli. 2010. "The Future of Public Debt: Prospects and Implications,” BIS Working Paper No. 300 (March).

Chamley, Christophe and Brian Pinto. 2011. "Why Official Bailouts Tend Not to Work: An Example Motivated by Greece 2010.” The Economists Voice (February), pp. 1-5. www.bepress.com.

Dooley, Michael and Michael Hutchison. 2009. "Transmission of the U.S. Subprime Crisis to Emerging Markets: Evidence on the decoupling-recoupling hypothesis,” Journal of International Money and Finance. 28, 1331-1349.

Fontana, Alessandro and Martin Scheicher. 2010. "An Analysis of Euro Area Sovereign CDS and their Relation with Government Bonds.” ECB Working Paper No. 1271 (December).

Gros, Daniel. 2010. "The senority conundrum: Bail out countries but bail in private, short-term creditors?” VOX December 5, 2010. www.voxeu.org

Lane, Phillip R. 2011. “The Irish Crisis.” CEPR Discussion Paper No. 8287 (March). 
Longstaff, Francis A., Jun Pan, Lasse H. Pedersen, and Kenneth J. Singleton. 2011. "How Sovereign is Sovereign Credit Risk?” American Economic Journal: Macroeconomics, 3(2), 75103.

Mayordomo, Sergio, Juan Ignacio Peña, and Eduardo S. Schwartz. 2010. “Are all Credit Default Swap Databases Equal?” NBER Working Paper No. 16590, December.

Micu, Marian, Eli Remolona and Philip Woolridge. 2006. “The Price Impact of Rating Announcements: Which Announcements Matter?” BIS Working Paper No. 207 (June).

Packer, Frank and Chamaree Suthiphongchai. 2003. "Sovereign Credit Default Swaps.” BIS Quarterly Review (December).

Packer, Frank and Haibin Zhu. 2005. “Contractual Terms and CDS Pricing,” BIS Quarterly Review, Part 8 (March), 89-100.

Tait, Nikki, and David Oakley. 2010. "Brussels gives sovereign CDS trading all-clear.” Financial Times, December $6^{\text {th }}$.

International Monetary Fund. 2011. Fiscal Monitor Update. 2011. IMF Fiscal Affairs

Department, January.

International Monetary Fund. 2011. Fiscal Monitor "Shifting Gears: Tackling Challenges on the Road to Fiscal Adjustment.” April.

Global Sovereign Credit Risk. 2010. Credit Market Analysis Ltd. London. Quarterly Report, December. 
Appendix A. Data Sources.

Sovereign CDS Spreads

Tax Base

Fiscal Balance/Tax Base

Public Debt/Tax Base

Trade/GDP

Inflation

External Debt/GDP

Nominal Depreciation

Foreign Reserves/GDP

Real GDP Growth

GDP per Capita

TED Spread
The CDS pricing is based on London closing values collected from a consortium of over thirty swap market participants CDS are denominated in US\$, except for the following in Euro: ct, cz, dk, hn, ic, ln, mr, po, rm, sx, sj, es, sd, tk, and ur. Source: CMA Datavision.

The ratio of tax divided by GDP, averaged over the period of previous five years to account for business cycle fluctuations. Source: World Bank's WDI, IMF Article IV Consultation documents, OECD, and Eurostat.

The ratio of fiscal balance/GDP divided by tax base; positive fiscal balance means fiscal surplus.

Source: World Bank's WDI, IMF Article IV Consultation documents, and Economist Intelligence Unit (EIU).

The ratio of public debt/GDP divided by tax base.

Source: IMF Fiscal Affairs Department, Article IV Consultation documents, and World Economic Outlook.

The ratio of (exports+imports) divided by GDP.

Source: WDI and EIU.

Annual consumer price inflation $(\%)$.

Source: WDI and EIU.

The ratio of total private and public external debt divided by GDP.

Source: WDI and EIU.

Annual depreciation of local currency against US\$ (\%)

Source: WDI and EIU.

The ratio of foreign reserves divided by GDP.

Source: WDI and EIU.

Annual growth of real GDP.

Source: WDI and EIU.

Real GDP per capita in US\$

Source: WDI and EIU.

The difference between the 3-month US\$ LIBOR and the 3-month US Treasury Bill (\%).

Source: Datastream. 
Appendix B. Country Details and Average Statistics for 2005-10.

\begin{tabular}{|c|c|c|c|c|c|c|c|c|c|c|c|}
\hline Group & Country & World Bank & Datastream & CDS 5-yr. & CDS 3-yr. & CDS 10-yr. & Fiscal Balance/Tax Base & Public Debt/Tax Base & Trade/GDP & Inflation (\%) & External Debt/GDF \\
\hline \multirow[t]{22}{*}{ Middle-Income } & Argentina & ARG & ag & 1075.29 & 1117.72 & 1124.23 & 0.07 & 4.40 & 0.43 & 9.42 & 0.46 \\
\hline & Brazil & BRA & $\mathrm{br}$ & 159.93 & 119.36 & 201.43 & -0.08 & 2.02 & 0.25 & 4.90 & 0.17 \\
\hline & Bulgaria & BGR & $\mathrm{bl}$ & 184.12 & 174.90 & 200.47 & 0.04 & 0.67 & 1.22 & 6.38 & 0.89 \\
\hline & China & $\mathrm{CHN}$ & $\mathrm{ch}$ & 65.01 & 54.53 & 74.05 & -0.09 & 1.13 & 0.62 & 2.97 & 0.10 \\
\hline & Colombia & $\mathrm{COL}$ & $\mathrm{cb}$ & 162.89 & 123.63 & 205.50 & -0.05 & 1.88 & 0.36 & 4.65 & 0.22 \\
\hline & Indonesia & IDN & id & 239.35 & 194.73 & 285.49 & -0.07 & 2.89 & 0.55 & 8.39 & 0.34 \\
\hline & Kazakhstan & KAZ & $\mathrm{kz}$ & 231.61 & 215.06 & 231.58 & -0.05 & 0.33 & 0.89 & 9.68 & 0.84 \\
\hline & Lebanon & LBN & $\mathrm{lb}$ & 355.40 & 313.76 & 390.27 & -0.65 & 10.98 & 0.69 & 4.30 & 1.12 \\
\hline & Lithuania & LTU & $\ln$ & 219.50 & 205.86 & 231.34 & -0.18 & 1.14 & 1.25 & 4.87 & 0.65 \\
\hline & Malaysia & MYS & my & 79.16 & 64.84 & 89.04 & -0.30 & 3.03 & 1.92 & 2.72 & 0.32 \\
\hline & Morocco & MAR & $\mathrm{mc}$ & 141.84 & 128.77 & 158.56 & -0.10 & 2.52 & 0.75 & 2.04 & 0.27 \\
\hline & Panama & PAN & $\mathrm{pa}$ & 147.52 & 112.87 & 186.98 & -0.03 & 4.80 & 1.49 & 4.25 & 0.53 \\
\hline & Peru & PER & pe & 161.63 & 124.87 & 201.94 & 0.06 & 2.20 & 0.48 & 2.59 & 0.27 \\
\hline & Phillipines & PHL & ph & 202.85 & 155.23 & 248.76 & -0.15 & 3.93 & 0.81 & 5.04 & 0.45 \\
\hline & Romania & ROM & $\mathrm{rm}$ & 224.50 & 225.68 & 243.59 & -0.14 & 0.87 & 0.74 & 6.52 & 0.54 \\
\hline & Russia & RUS & rs & 212.01 & 217.74 & 221.97 & 0.07 & 0.29 & 0.53 & 10.44 & 0.28 \\
\hline & South Africa & ZAF & sa & 137.14 & 121.33 & 157.06 & -0.06 & 1.22 & 0.61 & 5.08 & 0.14 \\
\hline & Thailand & THA & th & 95.42 & 81.22 & 109.01 & -0.08 & 2.68 & 1.40 & 3.24 & 0.26 \\
\hline & Tunisia & TUN & tu & 101.13 & 89.59 & 117.74 & -0.13 & 2.19 & 1.12 & 8.23 & 0.57 \\
\hline & Ukraine & UKR & ur & 898.71 & 930.54 & 898.67 & -0.08 & 0.68 & 0.97 & 13.71 & 0.57 \\
\hline & Venezuela & VEN & ve & 1024.69 & 1037.80 & 1011.23 & -0.20 & 2.49 & 0.52 & 22.82 & 0.23 \\
\hline & Vietnam & VNM & vi & 226.40 & 174.97 & 249.79 & -0.32 & 2.66 & 1.58 & 11.01 & 0.32 \\
\hline \multirow[t]{2}{*}{ High-Income (non OECD) } & Croatia & HRV & ct & 175.44 & 160.03 & 185.98 & -0.16 & 1.71 & 0.87 & 3.01 & 0.85 \\
\hline & Qatar & QAT & qa & 78.93 & 63.71 & 100.60 & 0.45 & 0.80 & 0.87 & 8.02 & 0.58 \\
\hline South-West Euro Area & Greece & GRC & $\mathrm{gr}$ & 264.49 & 223.60 & 215.45 & -0.27 & 3.60 & 0.54 & 5.49 & 1.46 \\
\hline \multirow{4}{*}{ Peripherals (SWEAP) } & Ireland & IRL & ir & 163.98 & 131.80 & 134.86 & -0.27 & 1.58 & 1.44 & 2.02 & 8.99 \\
\hline & Italy & ITA & it & 90.72 & 72.00 & 91.55 & -0.09 & 2.62 & 0.55 & 2.05 & 1.10 \\
\hline & Portugal & PRT & $\mathrm{pt}$ & 119.41 & 101.44 & 103.67 & -0.18 & 2.05 & 0.69 & 1.84 & 2.03 \\
\hline & Spain & ESP & es & 102.02 & 82.57 & 104.57 & -0.09 & 1.30 & 0.56 & 2.61 & 1.50 \\
\hline \multirow[t]{14}{*}{ OECD (non Euro) } & Australia & AUS & au & 41.52 & 32.55 & 49.27 & -0.02 & 0.46 & 0.40 & 2.91 & 0.95 \\
\hline & Chile & $\mathrm{CHL}$ & $\mathrm{cl}$ & 71.59 & 59.67 & 81.52 & 0.18 & 0.29 & 0.77 & 3.78 & 0.38 \\
\hline & Czech & CZE & $\mathrm{cz}$ & 65.23 & 54.69 & 73.90 & -0.09 & 0.87 & 1.47 & 2.72 & 0.41 \\
\hline & Denmark & DNK & $\mathrm{dk}$ & 50.59 & 35.87 & 61.70 & 0.04 & 0.84 & 0.98 & 2.20 & 1.72 \\
\hline & Hungary & HUN & $\mathrm{hn}$ & 189.46 & 169.18 & 184.27 & -0.15 & 1.86 & 1.54 & 5.16 & 1.01 \\
\hline & Iceland & ISL & ic & 288.02 & 303.63 & 266.12 & -0.07 & 1.47 & 0.81 & 7.15 & 6.77 \\
\hline & Israel & ISR & is & 81.52 & 67.28 & 96.03 & -0.06 & 2.30 & 0.80 & 2.68 & 0.52 \\
\hline & Japan & JPN & jp & 33.92 & 20.94 & 42.01 & -0.17 & 7.39 & 0.30 & -0.13 & 0.38 \\
\hline & Korea & KOR & ko & 97.59 & 89.40 & 107.91 & 0.03 & 1.23 & 0.90 & 3.14 & 0.35 \\
\hline & Mexico & MEX & $\mathrm{mx}$ & 118.24 & 97.59 & 142.15 & -0.05 & 2.31 & 0.58 & 4.27 & 0.19 \\
\hline & Norway & NOR & nw & 18.19 & 13.04 & 23.16 & 0.35 & 1.29 & 0.73 & 2.30 & 1.25 \\
\hline & Poland & POL & po & 96.25 & 82.10 & 102.61 & -0.07 & 1.48 & 0.81 & 2.67 & 0.46 \\
\hline & Sweden & SWE & sd & 52.76 & 37.19 & 66.38 & 0.03 & 0.88 & 0.94 & 1.68 & 1.86 \\
\hline & Turkey & TUR & tk & 201.54 & 165.60 & 242.63 & -0.10 & 1.78 & 0.49 & 8.13 & 0.39 \\
\hline \multirow[t]{7}{*}{ Euro (excluding SWEAP) } & Austria & AUT & oe & 55.06 & 43.84 & 55.61 & -0.05 & 1.49 & 1.07 & 1.88 & 2.05 \\
\hline & Belgium & BEL & bg & 61.43 & 39.22 & 50.78 & -0.06 & 2.06 & 1.59 & 2.37 & 2.97 \\
\hline & France & FRA & $\mathrm{fr}$ & 34.58 & 24.04 & 34.78 & -0.10 & 1.61 & 0.53 & 1.74 & 1.75 \\
\hline & Germany & DEU & $\mathrm{bd}$ & 23.77 & 16.76 & 24.59 & -0.05 & 1.97 & 0.83 & 1.65 & 1.44 \\
\hline & Netherlands & NLD & $\mathrm{nl}$ & 45.84 & 33.15 & 68.73 & -0.04 & 1.43 & 1.39 & 1.65 & 2.98 \\
\hline & Slovak & SVK & sx & 58.41 & 49.48 & 66.85 & -0.13 & 1.06 & 1.73 & 2.92 & 0.57 \\
\hline & Slovenia & SVN & $\mathrm{sj}$ & 51.91 & 41.17 & 60.92 & -0.06 & 0.75 & 1.28 & 2.74 & 0.97 \\
\hline
\end{tabular}


Table 1. Summary Statistics of Sovereign CDS Values and Fundamentals.

This table reports mean and standard deviation (in parenthesis) of sovereign CDS spreads (basis points) and macro fundamentals.

Tax Base is an average Tax/GDP over a period of previous 5 years. Appendix A provides data sources and Appendix B details the country groups.

\begin{tabular}{|c|c|c|c|c|c|c|c|c|c|c|c|c|c|c|c|}
\hline \multirow[b]{2}{*}{ Country } & \multicolumn{5}{|c|}{ Sovereign CDS 5-yr tenor (basis points) } & \multicolumn{5}{|c|}{ Fiscal Balance/Tax Base } & \multicolumn{5}{|c|}{ Public Debt/Tax Base } \\
\hline & 05-07 & 08 & 09 & 10 & $08-10$ & $05-07$ & 08 & 09 & 10 & $08-10$ & 05-07 & 08 & 09 & 10 & $08-10$ \\
\hline Spain & 16.7 & 100.7 & 113.5 & 347.7 & 187.3 & 0.05 & -0.12 & -0.31 & -0.27 & -0.23 & 1.1 & 1.1 & 1.5 & 1.7 & 1.4 \\
\hline Greece & 15.0 & 232.1 & 283.4 & 1026.5 & 514.0 & -0.18 & -0.29 & -0.48 & -0.33 & -0.37 & 3.2 & 3.5 & 4.0 & 4.5 & 4.0 \\
\hline Ireland & 8.6 & 181.0 & 158.0 & 619.2 & 319.4 & 0.05 & -0.24 & -0.47 & -1.08 & -0.60 & 0.9 & 1.5 & 2.2 & 3.2 & 2.3 \\
\hline Italy & 13.4 & 156.9 & 109.2 & 238.0 & 168.0 & -0.07 & -0.07 & -0.13 & -0.11 & -0.10 & 2.5 & 2.5 & 2.8 & 2.8 & 2.7 \\
\hline Portugal & 10.4 & 96.3 & 91.7 & 497.3 & 228.4 & -0.13 & -0.11 & -0.30 & -0.27 & -0.22 & 1.9 & 1.9 & 2.2 & 2.4 & 2.2 \\
\hline Middle-Income group & $\begin{array}{r}124.2 \\
(102.8)\end{array}$ & $\begin{array}{r}829.9 \\
(1069.4)\end{array}$ & $\begin{array}{r}295.2 \\
(331.3)\end{array}$ & $\begin{array}{r}233.2 \\
(221.5)\end{array}$ & $\begin{array}{r}452.8 \\
(540.7)\end{array}$ & $\begin{array}{r}-0.06 \\
(0.2)\end{array}$ & $\begin{array}{r}-0.08 \\
(0.2)\end{array}$ & $\begin{array}{r}-0.22 \\
(0.2)\end{array}$ & $\begin{array}{r}-0.19 \\
(0.1)\end{array}$ & $\begin{array}{r}-0.16 \\
(0.2)\end{array}$ & $\begin{array}{r}2.7 \\
(2.6)\end{array}$ & $\begin{array}{r}2.2 \\
(2.1)\end{array}$ & $\begin{array}{r}2.3 \\
(1.9)\end{array}$ & $\begin{array}{r}2.3 \\
(1.9)\end{array}$ & $\begin{array}{r}2.3 \\
(2.0)\end{array}$ \\
\hline High-Income (non OECD) & $\begin{array}{r}32.1 \\
(13.9)\end{array}$ & $\begin{array}{r}330.7 \\
(158.9)\end{array}$ & $\begin{array}{c}164.0 \\
(90.5)\end{array}$ & $\begin{array}{r}172.3 \\
(118.4)\end{array}$ & $\begin{array}{r}222.3 \\
(122.6)\end{array}$ & $\begin{array}{l}0.13 \\
(0.4)\end{array}$ & $\begin{array}{l}0.24 \\
(0.5)\end{array}$ & $\begin{array}{l}0.10 \\
(0.4)\end{array}$ & $\begin{array}{l}0.16 \\
(0.5)\end{array}$ & $\begin{array}{l}0.17 \\
(0.5)\end{array}$ & $\begin{array}{r}1.2 \\
(0.8)\end{array}$ & $\begin{array}{r}1.0 \\
(0.6)\end{array}$ & $\begin{array}{r}1.7 \\
(0.1)\end{array}$ & $\begin{array}{r}1.4 \\
(0.8)\end{array}$ & $\begin{array}{r}1.4 \\
(0.5)\end{array}$ \\
\hline OECD (non Euro) & $\begin{array}{r}34.8 \\
(41.5)\end{array}$ & $\begin{array}{r}260.3 \\
(238.8)\end{array}$ & $\begin{array}{r}120.3 \\
(103.5)\end{array}$ & $\begin{array}{r}117.8 \\
(96.4)\end{array}$ & $\begin{array}{r}166.2 \\
(146.2)\end{array}$ & $\begin{array}{l}0.04 \\
(0.2)\end{array}$ & $\begin{array}{c}0.01 \\
(0.2)\end{array}$ & $\begin{array}{r}-0.12 \\
(0.1)\end{array}$ & $\begin{array}{r}-0.08 \\
(0.1)\end{array}$ & $\begin{array}{r}-0.06 \\
(0.1)\end{array}$ & $\begin{array}{r}1.7 \\
(1.7)\end{array}$ & $\begin{array}{r}1.7 \\
(1.7)\end{array}$ & $\begin{array}{r}1.9 \\
(1.8)\end{array}$ & $\begin{array}{r}1.9 \\
(1.8)\end{array}$ & $\begin{array}{r}1.8 \\
(1.8)\end{array}$ \\
\hline Euro (excluding SWEAP) & $\begin{array}{r}11.0 \\
(13.3)\end{array}$ & $\begin{array}{r}95.1 \\
(40.2)\end{array}$ & $\begin{array}{r}54.2 \\
(24.6)\end{array}$ & $\begin{array}{r}101.3 \\
(55.2)\end{array}$ & $\begin{array}{r}83.5 \\
(40.0)\end{array}$ & $\begin{array}{r}-0.03 \\
(0.0)\end{array}$ & $\begin{array}{r}-0.02 \\
(0.0)\end{array}$ & $\begin{array}{r}-0.15 \\
(0.1)\end{array}$ & $\begin{array}{r}-0.14 \\
(0.1)\end{array}$ & $\begin{array}{r}-0.10 \\
(0.1)\end{array}$ & $\begin{array}{r}1.4 \\
(0.5)\end{array}$ & $\begin{array}{r}1.4 \\
(0.5)\end{array}$ & $\begin{array}{r}1.6 \\
(0.5)\end{array}$ & $\begin{array}{r}1.7 \\
(0.4)\end{array}$ & $\begin{array}{r}1.6 \\
(0.5)\end{array}$ \\
\hline & & & ide/GDF & & & & Infla & $n(\%)$ & & & & terna & $\mathrm{ebt} / \mathrm{G}$ & & \\
\hline & $05-07$ & 08 & 09 & 10 & $08-10$ & $05-07$ & 08 & 09 & 10 & $08-10$ & $05-07$ & 08 & 09 & 10 & $08-10$ \\
\hline Spain & 0.6 & 0.6 & 0.5 & 0.5 & 0.5 & 3.55 & 1.40 & 0.80 & 2.78 & 1.66 & 1.4 & 1.5 & 1.7 & 1.5 & 1.6 \\
\hline Greece & 0.6 & 0.6 & 0.5 & 0.5 & 0.5 & 3.32 & 2.64 & 2.97 & 17.34 & 7.65 & 1.3 & 1.4 & 1.8 & 1.7 & 1.7 \\
\hline Ireland & 1.5 & 1.6 & 1.6 & 0.9 & 1.4 & 3.75 & 4.05 & -4.48 & 1.30 & 0.29 & 7.8 & 8.9 & 10.7 & 11.0 & 10.2 \\
\hline Italy & 0.6 & 0.6 & 0.5 & 0.6 & 0.5 & 2.30 & 2.26 & 1.02 & 2.10 & 1.79 & 1.1 & 1.0 & 1.2 & 1.1 & 1.1 \\
\hline Portugal & 0.7 & 0.8 & 0.6 & 0.7 & 0.7 & 2.60 & 0.71 & 0.00 & 2.52 & 1.08 & 1.9 & 1.9 & 2.3 & 2.4 & 2.2 \\
\hline Middle-Income group & $\begin{array}{r}0.9 \\
(0.5)\end{array}$ & $\begin{array}{r}0.9 \\
(0.5)\end{array}$ & $\begin{array}{r}0.8 \\
(0.4)\end{array}$ & $\begin{array}{r}0.9 \\
(0.5)\end{array}$ & $\begin{array}{r}0.9 \\
(0.4)\end{array}$ & $\begin{array}{l}6.74 \\
(4.7)\end{array}$ & $\begin{array}{l}9.73 \\
(6.8)\end{array}$ & $\begin{array}{l}5.24 \\
(5.9)\end{array}$ & $\begin{array}{l}6.61 \\
(5.4)\end{array}$ & $\begin{array}{l}7.19 \\
(6.0)\end{array}$ & $\begin{array}{r}0.5 \\
(0.3)\end{array}$ & $\begin{array}{r}0.4 \\
(0.3)\end{array}$ & $\begin{array}{r}0.4 \\
(0.3)\end{array}$ & $\begin{array}{r}0.4 \\
(0.2)\end{array}$ & $\begin{array}{r}0.4 \\
(0.3)\end{array}$ \\
\hline High-Income (non OECD) & $\begin{array}{r}0.9 \\
(0.0)\end{array}$ & $\begin{array}{r}0.9 \\
(0.1)\end{array}$ & $\begin{array}{r}0.8 \\
(0.0)\end{array}$ & $\begin{array}{r}0.8 \\
(0.0)\end{array}$ & $\begin{array}{r}0.8 \\
(0.0)\end{array}$ & $\begin{array}{l}8.20 \\
(6.2)\end{array}$ & $\begin{array}{l}8.02 \\
(7.3)\end{array}$ & $\begin{array}{c}-0.90 \\
(3.9)\end{array}$ & $\begin{array}{l}1.37 \\
(0.7)\end{array}$ & $\begin{array}{l}2.83 \\
(4.0)\end{array}$ & $\begin{array}{r}0.6 \\
(0.2)\end{array}$ & $\begin{array}{r}0.7 \\
(0.2)\end{array}$ & $\begin{array}{r}0.9 \\
(0.2)\end{array}$ & $\begin{array}{r}0.8 \\
(0.2)\end{array}$ & $\begin{array}{r}0.8 \\
(0.2)\end{array}$ \\
\hline OECD (non Euro) & $\begin{array}{r}0.8 \\
(0.3)\end{array}$ & $\begin{array}{r}0.9 \\
(0.4)\end{array}$ & $\begin{array}{r}0.8 \\
(0.3)\end{array}$ & $\begin{array}{r}0.8 \\
(0.4)\end{array}$ & $\begin{array}{r}0.8 \\
(0.4)\end{array}$ & $\begin{array}{l}3.38 \\
(2.3)\end{array}$ & $\begin{array}{l}4.60 \\
(3.4)\end{array}$ & $\begin{array}{l}3.02 \\
(3.5)\end{array}$ & $\begin{array}{l}3.08 \\
(1.4)\end{array}$ & $\begin{array}{l}3.57 \\
(2.8)\end{array}$ & $\begin{array}{r}1.0 \\
(1.1)\end{array}$ & $\begin{array}{r}1.3 \\
(2.0)\end{array}$ & $\begin{array}{r}1.5 \\
(2.5)\end{array}$ & $\begin{array}{r}1.5 \\
(2.4)\end{array}$ & $\begin{array}{r}1.4 \\
(2.3)\end{array}$ \\
\hline Euro (excluding SWEAP) & $\begin{array}{r}1.2 \\
(0.4)\end{array}$ & $\begin{array}{r}1.3 \\
(0.4)\end{array}$ & $\begin{array}{r}1.2 \\
(0.5)\end{array}$ & $\begin{array}{r}1.2 \\
(0.4)\end{array}$ & $\begin{array}{r}1.2 \\
(0.4)\end{array}$ & $\begin{array}{l}2.56 \\
(1.0)\end{array}$ & $\begin{array}{c}2.13 \\
(1.1)\end{array}$ & $\begin{array}{c}0.94 \\
(0.5)\end{array}$ & $\begin{array}{l}2.05 \\
(0.6)\end{array}$ & $\begin{array}{l}1.71 \\
(0.7)\end{array}$ & $\begin{array}{r}1.8 \\
(1.0)\end{array}$ & $\begin{array}{r}1.8 \\
(0.9)\end{array}$ & $\begin{array}{r}2.0 \\
(0.9)\end{array}$ & $\begin{array}{r}1.9 \\
(0.9)\end{array}$ & $\begin{array}{r}1.9 \\
(0.9)\end{array}$ \\
\hline
\end{tabular}


Table 2. Dynamics of CDS Spreads. The dependent variable (y) is sovereign CDS 5-year tenor in basis points.

South-West Euro Area Periphery (SWEAP) includes Greece, Ireland, Italy, Portugal, and Spain.

Tax Base is an average Tax/GDP over a period of previous 5 years. TED Spread (3-month US\$ LIBOR - 3-month US Treasury) and Inflation are in percent. All variables are in realtime $(\mathrm{t})$, except the lagged CDS, $\mathrm{y}(\mathrm{t}-1)$. Standard errors are in parentheses, with $* * *(* *, *)$ denoting statistical significance at $1(5,10)$ level.

(1)

coeff. (s.e.)

$\mathrm{t} 2008$

$\mathrm{t} 2009$

$\mathrm{t} 2010$

t2008 x Euro dummy

t2009 x Euro dummy

t2010 x Euro dummy

t2008 x SWEAP

t2009 x SWEAP

t2010 x SWEAP

TED Spread

$\mathrm{y}(\mathrm{t}-1)$

Trade/GDP

Inflation

External Debt/GDP

Public Debt/Tax Base

Fiscal Balance/Tax Base

constant term

$\mathrm{R}^{2}$

Observations

Countries (i)

Fixed Effects (i)

Serial Correlation

Clustered s.e. (i)
(2)

Balanced (Whole) Sample: 2005-10

$334.1(102.3) * * *$

$-4.7(21.0)$

$58.8(12.7) \quad * *$

$-216.0(84.5)$

80.5 (30.4) ***

$56.2(24.3) * *$

$-194.4(93.2) *$

$136.1(30.8) \quad * * *$

324.4 (58.1) $\quad * * *$

$-0.8(13.6)$

$0.3(0.1) \quad * * *$

$-24.9(29.2)$

$24.6(6.2) \quad * * *$

$7.9(2.3) \quad * * *$

$14.7(3.9) \quad * * *$

-87.7 (25.6) ***

0.48

300

50

No

$\mathrm{y}(\mathrm{t}-1)$

Yes
(3)

coeff. (s.e.)

$328.0(78.0) \quad * * *$

$-36.8(33.7)$

$2.5(32.6)$

$-225.3(82.3) \quad * * *$

$14.6(30.1)$

$5.2(26.6)$

$-249.5(98.2) \quad * *$

18.7 (58.6)

$174.4(107.9)$

$3.2(27.3)$

$0.2(0.1) \quad * * *$

$-86.1(150.7)$

24.5 (11.9) **

$-36.6(30.1)$

$-829.4(302.0) \quad * * *$

286.0 (271.7)

0.52

300

50

$\mathrm{y}(\mathrm{t}-1)$

No
(4)

coeff. (s.e.)

349.3 (97.5) ***

$-35.5(16.7)$

42.5 (14.0) ***

$-238.6(80.3) * * *$

$84.2(29.4) \quad * * *$

$48.0(26.5)$

$-235.6(86.6) \quad * * *$

$113.8(34.1) \quad * * *$

$287.7(53.6) \quad * * *$

$1.3(11.3)$

$0.3(0.0) \quad * * *$

$-41.9(28.1)$

$23.8(6.0) \quad * * *$

$3.7(2.3)$

$-194.1(55.9) \quad * * *$

$-37.3(26.0)$

0.48

300

50

$\mathrm{y}(\mathrm{t}-1)$
Yes 
Table 3. CDS Spreads, Fundamentals and Structural Change. The dependent variable (y) is sovereign CDS 5-year tenor in basis points.

Tax Base is an average Tax/GDP over a period of previous 5 years. TED Spread (3-month US\$ LIBOR - 3-month US Treasury) and Inflation are in percent.

All variables are in realtime $(\mathrm{t})$, except the lagged CDS, $\mathrm{y}(\mathrm{t}-1)$. Standard errors are in parentheses, with $* * *(* *, *)$ denoting statistical significance at $1(5,10)$ level.

\begin{tabular}{|c|c|c|c|c|c|c|c|c|c|c|c|c|}
\hline & (1) & & (2) & & (3) & & (4) & & $(5)$ & & (6) & \\
\hline Sample & Years 2005-10 & & Years 2005-10 & & Years 2005-10 & & Years 2005-10 & & Years 2005-07 & & Years 2005-07 & \\
\hline & coeff. (s.e.) & & coeff. (s.e.) & & coeff. (s.e.) & & coeff. (s.e.) & & coeff. (s.e.) & & coeff. (s.e.) & \\
\hline TED Spread & $-29.6(38.7)$ & & $17.5(12.1)$ & & $64.1(42.2)$ & & $43.6(13.2)$ & $* * *$ & $34.5(10.2)$ & $* * *$ & $23.2(7.7)$ & $* * *$ \\
\hline $\mathrm{y}(\mathrm{t}-1)$ & $0.3(0.1)$ & $* * *$ & $0.3(0.0)$ & $* * *$ & $0.2(0.1)$ & $* * *$ & $0.3(0.0)$ & $* * *$ & $0.0(0.1)$ & & $0.4(0.1)$ & $* * *$ \\
\hline Trade/GDP & $-186.7(168.9)$ & & $1.2(21.9)$ & & $182.7(182.2)$ & & $-12.4(25.3)$ & & $-92.8(50.8)$ & $*$ & $-14.0(9.3)$ & \\
\hline Inflation & $38.6(12.3)$ & $* * *$ & $28.1(3.0)$ & $* * *$ & $35.7(12.9)$ & $* * *$ & $29.9(3.5)$ & $* * *$ & $9.8(2.2)$ & $* * *$ & $8.7(1.3)$ & $* * *$ \\
\hline External Debt/GDP & $57.0(32.9)$ & $*$ & $17.0(3.5)$ & $* * *$ & $-53.9(37.2)$ & & $9.8(4.7)$ & $* *$ & $-13.7(11.2)$ & & $0.6(1.3)$ & \\
\hline Public Debt/Tax Base & $48.2(48.7)$ & & $13.8(4.6)$ & $* * *$ & & & & & $123.4(33.1)$ & $* * *$ & $18.3(3.0)$ & $* * *$ \\
\hline Fiscal Balance/Tax Base & & & & & $-910.3(236.2)$ & $* * *$ & $-418.7(87.1)$ & $* * *$ & & & & \\
\hline constant term & $-389.5(541.5)$ & & $-87.3(20.7)$ & $* * *$ & $-501.7(267.5)$ & $*$ & $-82.5(30.0)$ & $* * *$ & $81.9(100.1)$ & & $-44.1(10.9)$ & $* * *$ \\
\hline $\mathrm{R}^{2}$ & 0.19 & & 0.35 & & 0.18 & & 0.35 & & 0.84 & & 0.76 & \\
\hline Observations & 300 & & 300 & & 300 & & 300 & & 150 & & 150 & \\
\hline Countries (i) & 50 & & 50 & & 50 & & 50 & & 50 & & 50 & \\
\hline Fixed Effects (i) & Yes & & No & & Yes & & No & & Yes & & No & \\
\hline Serial Correlation & $\mathrm{y}(\mathrm{t}-1)$ & & $\mathrm{y}(\mathrm{t}-1)$ & & $\mathrm{y}(\mathrm{t}-1)$ & & $\mathrm{y}(\mathrm{t}-1)$ & & $\mathrm{y}(\mathrm{t}-1)$ & & $\mathrm{y}(\mathrm{t}-1)$ & \\
\hline Clustered s.e. (i) & No & & Yes & & No & & Yes & & No & & Yes & \\
\hline & $(7)$ & & $(8)$ & & (9) & & $(10)$ & & $(11)$ & & $(12)$ & \\
\hline Sample & $\begin{array}{c}\text { Years } 2005-07 \\
\text { coeff. (s.e.) }\end{array}$ & & $\begin{array}{c}\text { Years } 2005-07 \\
\text { coeff. (s.e.) }\end{array}$ & & $\begin{array}{c}\text { Years } 2008-10 \\
\text { coeff. (s.e.) }\end{array}$ & & $\begin{array}{c}\text { Years } 2008-10 \\
\text { coeff. (s.e.) }\end{array}$ & & $\begin{array}{c}\text { Years } 2008-10 \\
\text { coeff. (s.e.) }\end{array}$ & & $\begin{array}{c}\text { Years } 2008-10 \\
\text { coeff. (s.e.) }\end{array}$ & \\
\hline TED Spread & $21.7(7.7)$ & $* * *$ & $24.9(6.6)$ & $* * *$ & $150.2(42.1)$ & $* * *$ & $190.6(65.7)$ & $* * *$ & $186.7(45.1)$ & $* * *$ & $197.3(62.8)$ & $* * *$ \\
\hline $\mathrm{y}(\mathrm{t}-1)$ & $0.2(0.1)$ & $* * *$ & $0.5(0.1)$ & $* * *$ & $-0.1(0.1)$ & & $0.2(0.0)$ & $* * *$ & $-0.1(0.1)$ & & $0.2(0.0)$ & $* * *$ \\
\hline Trade/GDP & $-58.9(37.5)$ & & $-24.6(9.1)$ & $* * *$ & $-489.7(244.5)$ & $* *$ & $-94.5(63.7)$ & & $-191.4(199.6)$ & & $-96.4(65.2)$ & \\
\hline Inflation & $6.5(1.7)$ & $* * *$ & $7.5(1.4)$ & $* * *$ & $29.5(11.6)$ & $* *$ & $52.2(5.3)$ & $* * *$ & $27.2(9.0)$ & $* * *$ & $52.9(5.2)$ & $* * *$ \\
\hline External Debt/GDP & $-5.2(9.6)$ & & $1.4(1.4)$ & & $189.3(138.7)$ & & $28.6(13.0)$ & $* *$ & $33.0(102.2)$ & & $21.5(12.2)$ & $*$ \\
\hline Public Debt/Tax Base & & & & & $-182.1(218.7)$ & & $14.4(13.1)$ & & & & & \\
\hline Fiscal Balance/Tax Base & $-291.7(86.5)$ & $* * *$ & $-202.9(40.2)$ & $* * *$ & & & & & $-567.4(606.0)$ & & $-150.7(163.8)$ & \\
\hline constant term & $107.4(78.7)$ & & $-6.8(12.4)$ & & $-621.4(1134.7)$ & & $-82.0(64.0)$ & & $-200.3(801.8)$ & & $-61.9(59.9)$ & \\
\hline $\mathrm{R}^{2}$ & 0.89 & & 0.68 & & 0.58 & & 0.45 & & 0.61 & & 0.45 & \\
\hline Observations & 150 & & 150 & & 150 & & 150 & & 150 & & 150 & \\
\hline Countries (i) & 50 & & 50 & & 50 & & 50 & & 50 & & 50 & \\
\hline Fixed Effects (i) & Yes & & No & & Yes & & No & & Yes & & No & \\
\hline Serial Correlation & $\mathrm{y}(\mathrm{t}-1)$ & & $\mathrm{y}(\mathrm{t}-1)$ & & $\mathrm{y}(\mathrm{t}-1)$ & & $\mathrm{y}(\mathrm{t}-1)$ & & $\mathrm{y}(\mathrm{t}-1)$ & & $\mathrm{y}(\mathrm{t}-1)$ & \\
\hline Clustered s.e. (i) & No & & Yes & & No & & Yes & & No & & Yes & \\
\hline
\end{tabular}


Table 4. Prediction Errors of Sovereign CDS Spreads. Based on the predicted values from estimation in Table 3 (eqs. (3) and (9)) using CDS 5-year tenor. The out-sample prediction uses 2005-07 (pre-crisis period) observations. The in-sample prediction uses 2005-10 (whole sample) observations.

Where Actual CDS > Predicted CDS, there is a signal of under-prediction (i.e. the sovereign default risk is over-priced).

The min and max provide lower and upper bounds of prediction errors extracted from the all the specifications with Fiscal Balance/Tax Base and macro controls.

Country/Group

Spain

Greece

Ireland

Italy

Portugal

Middle-Income group

OECD (non Euro)

Euro (excluding SWEAP) out (in) sample prediction

out

in

out

in

out

in

out

in

out

in

out

in

out

in

out

in
Prediction Error $=$ Actual CDS values divided by Predicted CDS values

$$
2008 \quad 2009 \quad 2010 \quad 2008-10
$$

3.9

3.6

4.0

6.5

4.1

4.7

3.5

2.7

2.3

2.2

1.8

3.3

1.7

1.9

$\begin{array}{ll}4.2 & 3.8\end{array}$

0.8

$\mathbf{1 . 7}$

7.9

2.6

1.7

2.6

2.3

1.6

1.9

3.6

3.3

2.8

3.2

2.9

4.0

6.9

4.5

4.2

3.9

2.7

1.0

1.2

1.8

1.2

2.3

31.6

2.6

1.6

5.4

12.9

1.2

1.4

1.7

5.0

2.1

5.8

13.7

3.2 
Table 5. Matching Middle-Income Countries to SWEAP Group.

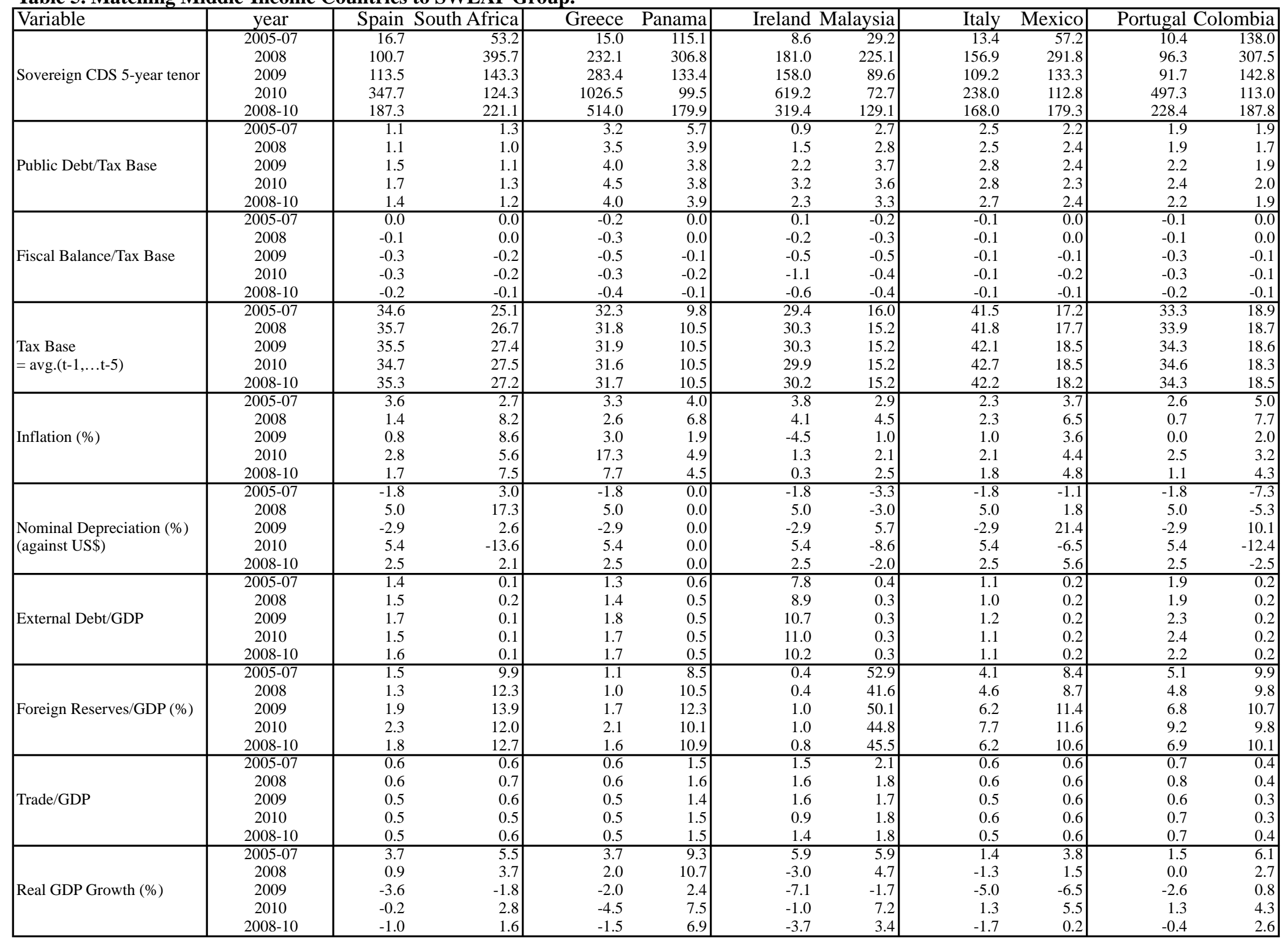


Appendix C.1. Dynamics of CDS Spreads 3-Year and 10-Year Tenor. This table provides a robustness check to Tables 2 and 3 across CDS 5, 3, and 10 tenor. The dependent variable (y) is sovereign CDS 3-year and 10-year tenor in basis points. SWEAP includes Greece, Ireland, Italy, Portugal, and Spain.

Tax Base is an average Tax/GDP over a period of previous 5 years. TED Spread (3-month US\$ LIBOR - 3-month US Treasury) and Inflation are in percent. All variables are in realtime $(\mathrm{t})$, except the lagged CDS, $\mathrm{y}(\mathrm{t}-1)$. Standard errors are in parentheses, with $* * *(* *, *)$ denoting statistical significance at $1(5,10)$ level.

\begin{tabular}{|c|c|c|c|c|c|c|c|c|c|c|c|c|}
\hline & \multicolumn{4}{|c|}{ Whole Sample 2005-10 } & \multicolumn{4}{|c|}{ Tranquility 2005-07 } & \multicolumn{4}{|c|}{ Crisis 2008-10 } \\
\hline t2008 & $304.2(102.3)$ & $* * *$ & $349.4(104.2)$ & $* * *$ & & & & & & & & \\
\hline t2010 & $63.9(14.2)$ & $* * *$ & $66.7(14.9)$ & $* * *$ & & & & & & & & \\
\hline t2008 x Euro dummy & $-194.1(82.2)$ & $* *$ & $-232.9(85.6)$ & $* * *$ & & & & & & & & \\
\hline t2009 x Euro dummy & $73.3(30.5)$ & ** & $91.5(34.7)$ & $* * *$ & & & & & & & & \\
\hline t2009 x SWEAP & $118.9(31.4)$ & $* * *$ & 151.0 & $* * *$ & & & & & & & & \\
\hline t2010 x SWEAP & $226.4(48.4)$ & $* * *$ & $158.7(36.2)$ & $* * *$ & & & & & & & & \\
\hline TED Spread & $-0.5(13.1)$ & & $-1.4(14.8)$ & & $35.3(9.4)$ & *** & $28.8(11.1)$ & $* * *$ & $155.1(43.1)$ & *** & $134.0(38.0)$ & $* * *$ \\
\hline$y(t-1)$ & $0.3(0.0)$ & $* * *$ & $0.3(0.1)$ & $* * *$ & $-0.1(0.1)$ & & $0.1(0.1)$ & & $-0.1(0.1)$ & & $-0.1(0.1)$ & \\
\hline Trade/GDP & $-20.9(32.3)$ & & $-38.1(29.9)$ & & $-70.3(45.6)$ & & $-126.8(60.4)$ & $* *$ & $-477.5(245.3)$ & * & $-438.5(232.9)$ & * \\
\hline Inflation & $22.3(6.9)$ & $* * *$ & $25.0(6.1)$ & $* * *$ & $6.4(2.2)$ & $* * *$ & $12.1(2.6)$ & $* * *$ & $27.2(11.6)$ & ** & $26.6(10.6)$ & ** \\
\hline External Debt/GDP & $8.4(1.8)$ & $* * *$ & $5.0(3.0)$ & & $-14.8(9.6)$ & & $-16.9(14.8)$ & & 194.4 (138.7) & & $207.6(120.7)$ & $*$ \\
\hline Countries (i) & 50 & & 50 & & 50 & & 50 & & 50 & & 50 & \\
\hline Fixed Effects (i) & No & & No & & No & & No & & No & & No & \\
\hline Serial Correlation & $\mathrm{y}(\mathrm{t}-1)$ & & $\mathrm{y}(\mathrm{t}-1)$ & & $\mathrm{y}(\mathrm{t}-1)$ & & $\mathrm{y}(\mathrm{t}-1)$ & & $\mathrm{y}(\mathrm{t}-1)$ & & $\mathrm{y}(\mathrm{t}-1)$ & \\
\hline Clustered s.e. (i) & Yes & & Yes & & Yes & & Yes & & Yes & & Yes & \\
\hline
\end{tabular}


Appendix C.2. Dynamics of CDS Spreads (continued). This table provides robustness checks to results in Tables 2 and 3.

The dependent variable (y) is sovereign CDS 5-year tenor in basis points. SWEAP includes Greece, Ireland, Italy, Portugal, and Spain.

Tax Base is an average Tax/GDP over a period of previous 5 years. TED Spread (3-month US\$ LIBOR - 3-month US Treasury) and Inflation are in percent. The Sargan test of over-identifying restrictions has a null hypothesis of exogenous instruments. The AR(\#) test has a null of no autocorrelation in \# differences. All variables are in realtime $(\mathrm{t})$, except the lagged CDS. Standard errors are in parentheses, with $* * *(* *, *)$ denoting statistical significance at $1(5,10)$ level.

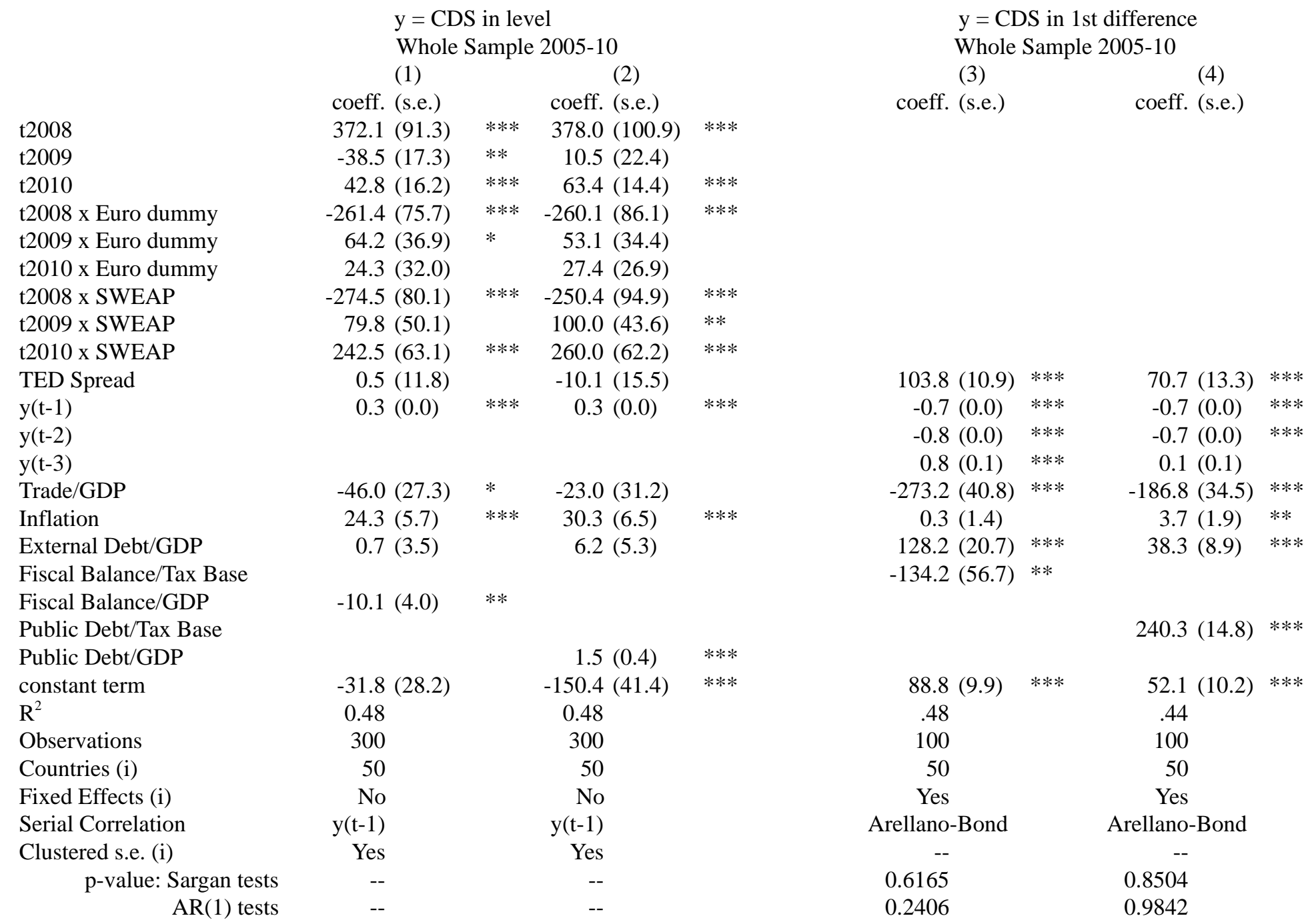


Figure 1. Global Sovereign CDS Positions in Early 2011.

This figure provides the gross notional amount of outstanding sovereign CDS positions (billion US\$) as of February 25, 2011.

Source: Depository Trust \& Clearing Corporation (DTCC).

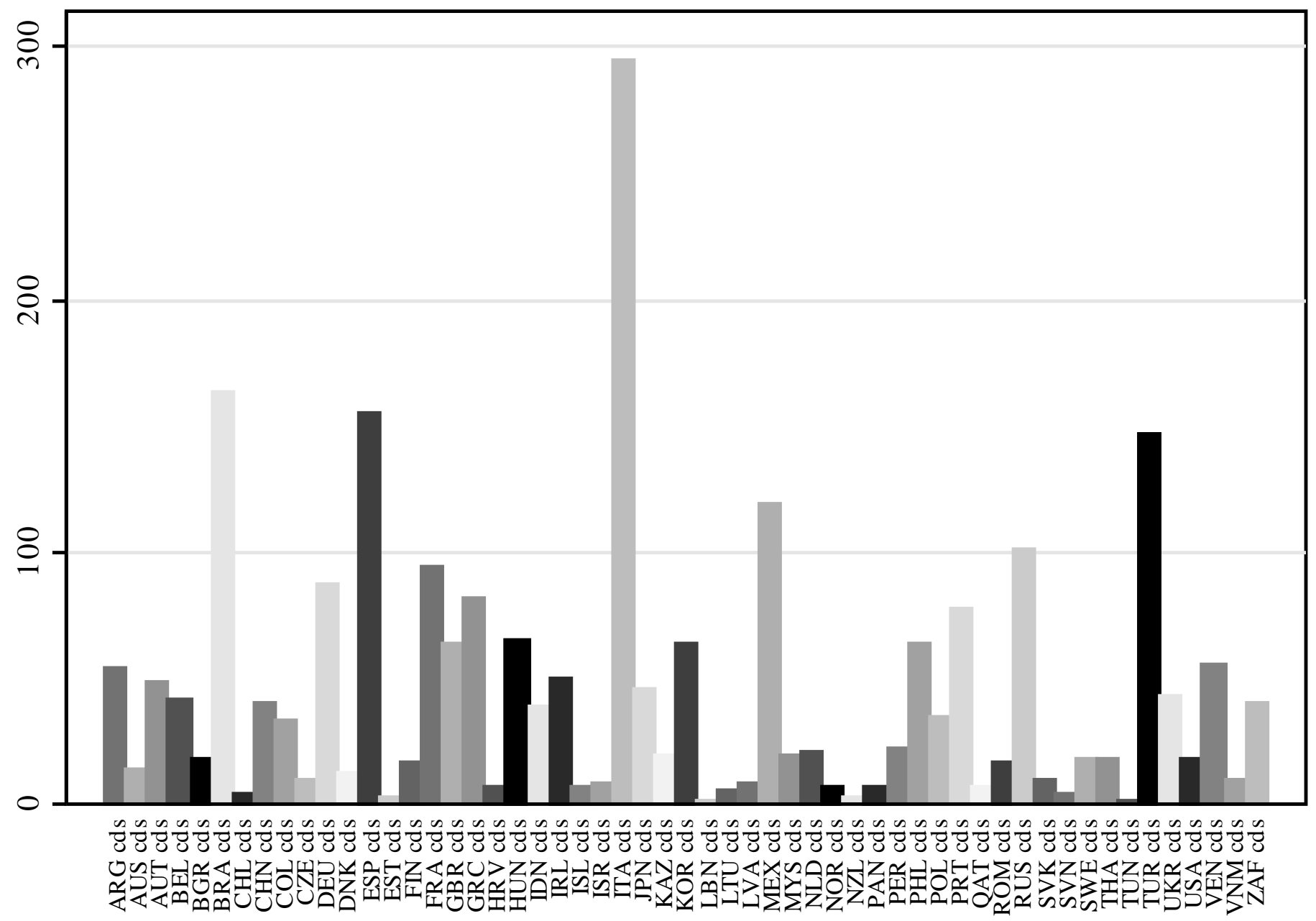


Figure 2. Evolution of Sovereign CDS Prices. This figure plots CDS 5-year tenor (basis points) for selected middle-income countries and Eurozone members.
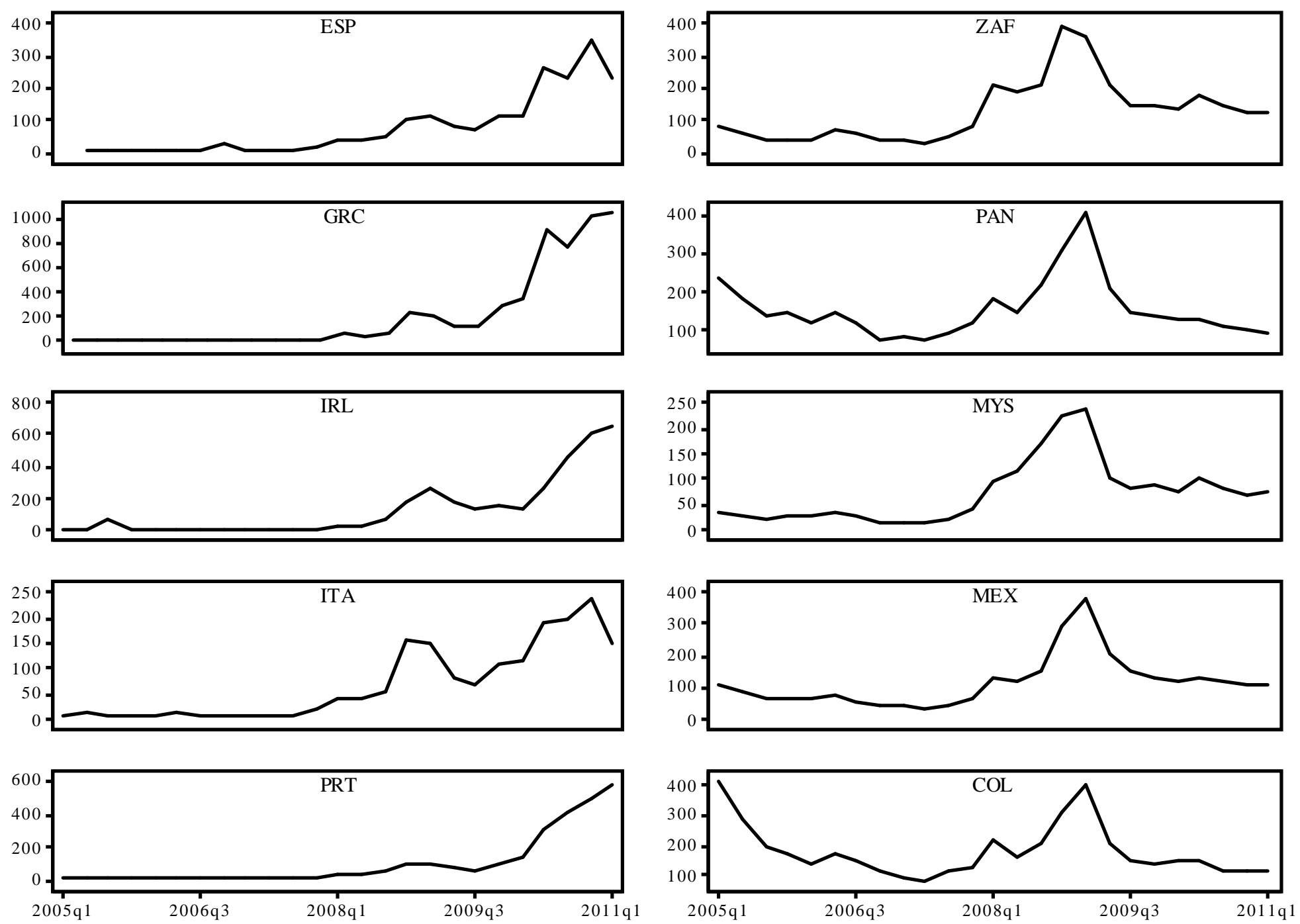
Figure 3. Fiscal Space in 2005-07. Public debt/GDP divided by tax base (an average Tax/GDP over a period of previous 5 years).

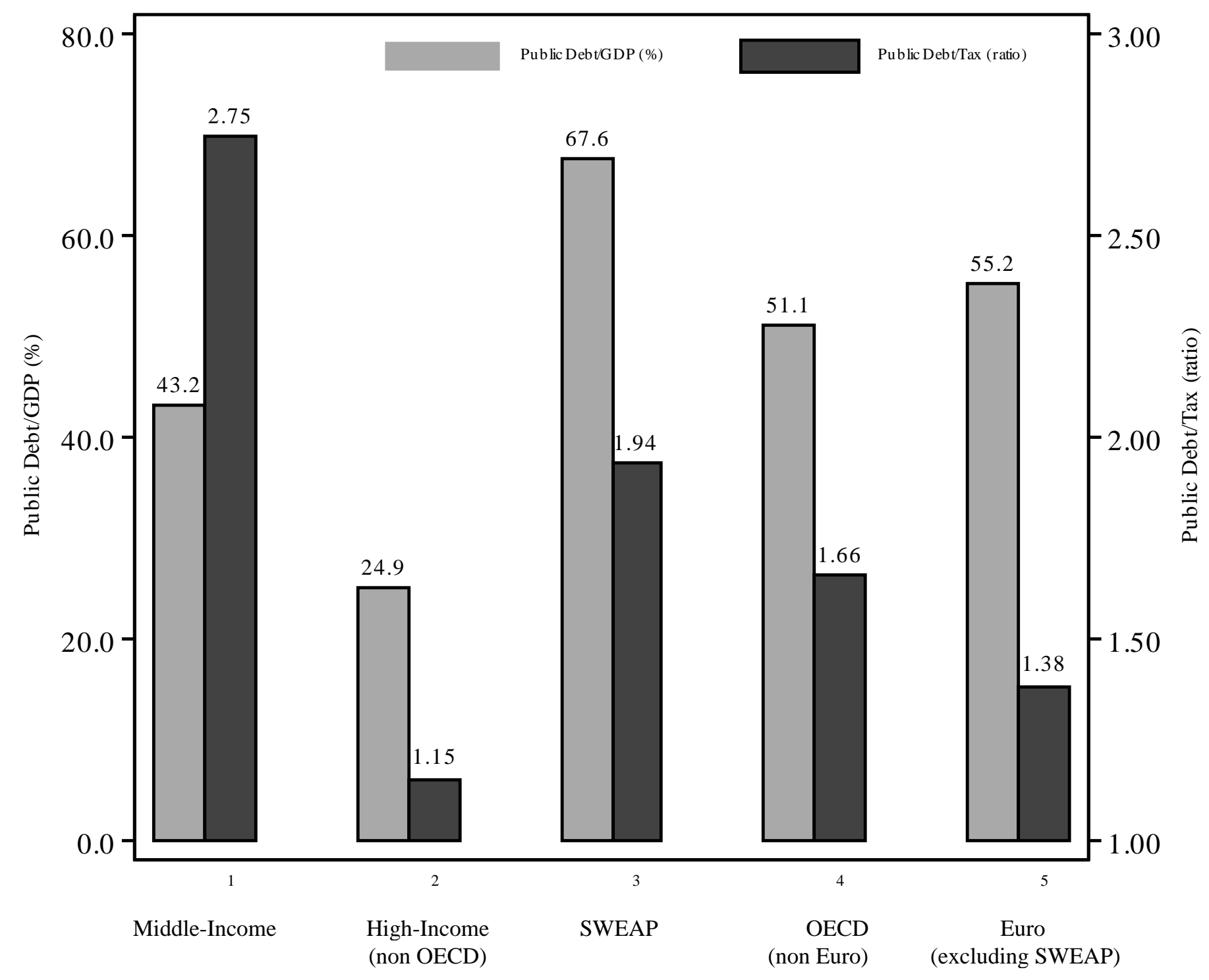


Figure 3. Fiscal Space in 2005-07 (continued). Fiscal balance/GDP divided by tax base (an average Tax/GDP over a period of previous 5 years).

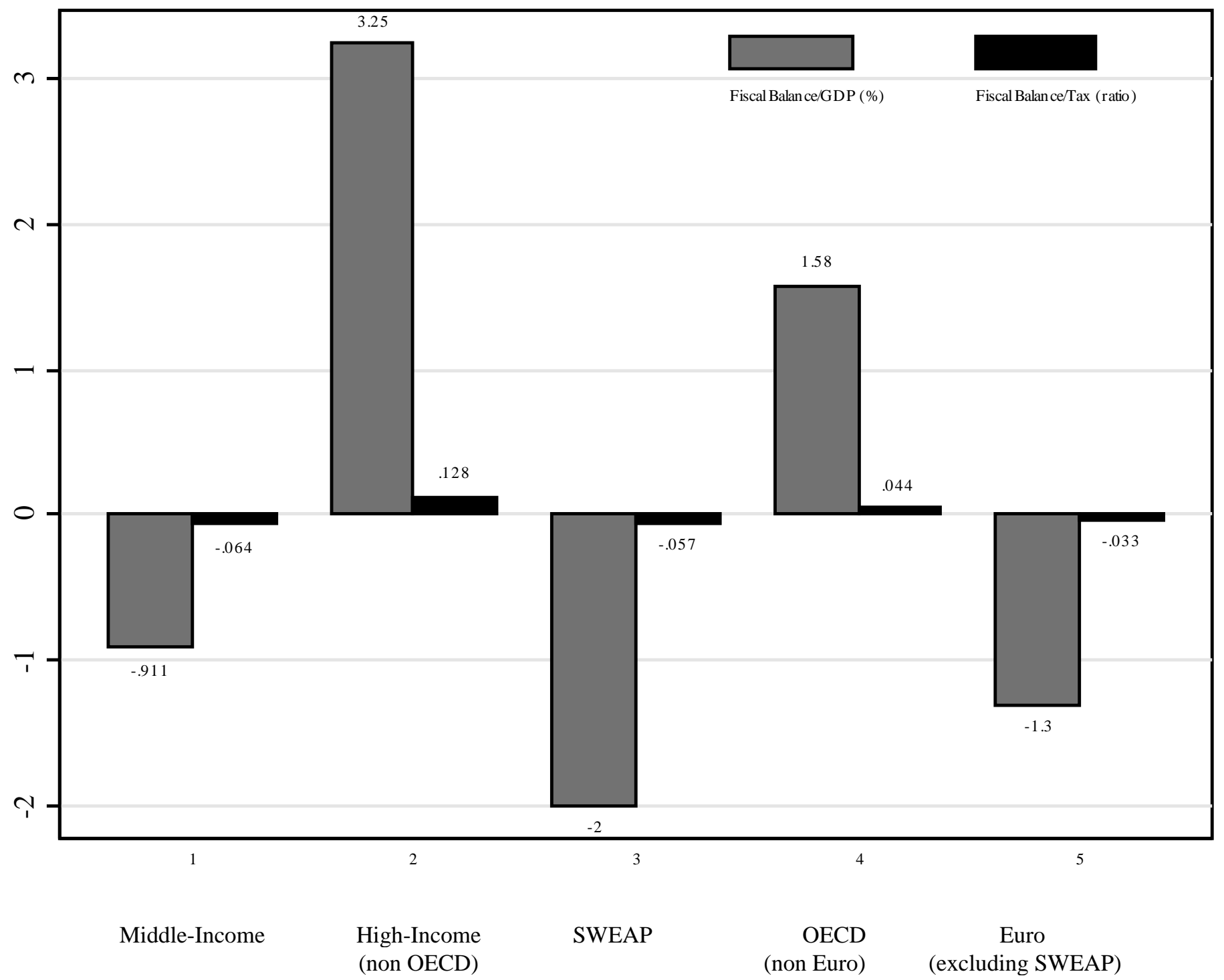


Figure 4. Market Overreaction to Fiscal Pre-Conditions. Based on the out-sample predictions eqs. 6 and 8 in Table 3 (as summarized in Table 4).

The prediction error is the actual CDS divided by the predicted CDS; when >1, there is a signal of under-prediction (i.e. the sovereign default risk is over-priced).

This figure plots 2008-10 prediction errors on CDS 5-year tenor on the vertical axis. The 2005-07 fiscal space is on the horizontal axis.
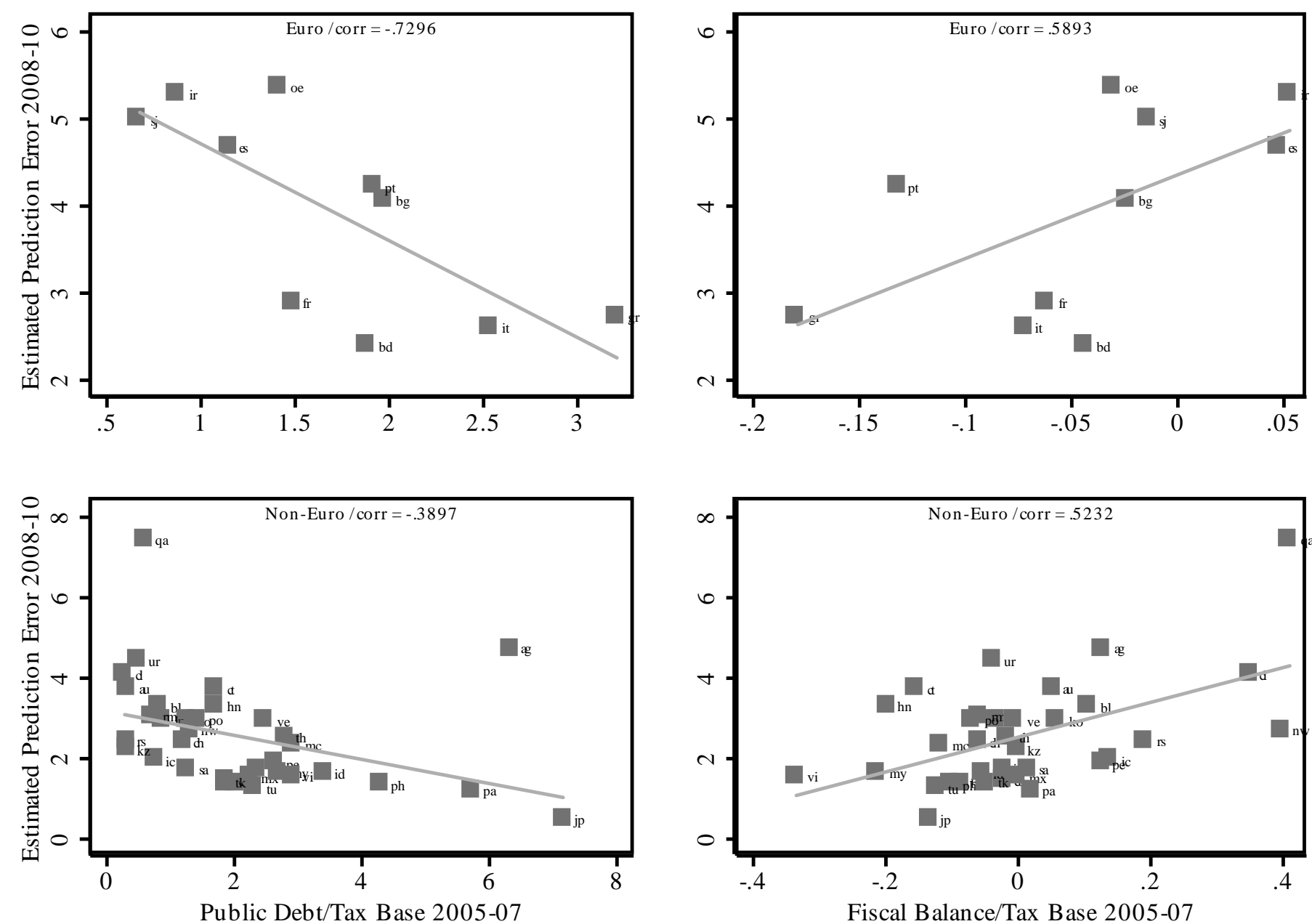
Figure 5. Fiscal Space and Prediction Error on the Sovereign CDS 5-Year Tenor -- SWEAP Countries and Matched Middle-Income Group. Based on the in-sample predictions eqs. 2 and 4 in Table 3 (as summarized in Table 4). The circle size is proportional to 2005-07 public debt/tax base.

The prediction error is the actual CDS divided by the predicted CDS; when >1, there is a signal of under-prediction (i.e. the sovereign default risk is over-priced).

This figure plots 2008-10 prediction errors on CDS 5-year tenor on the vertical axis. The 2005-07 prediction errors are on the horizontal axis.

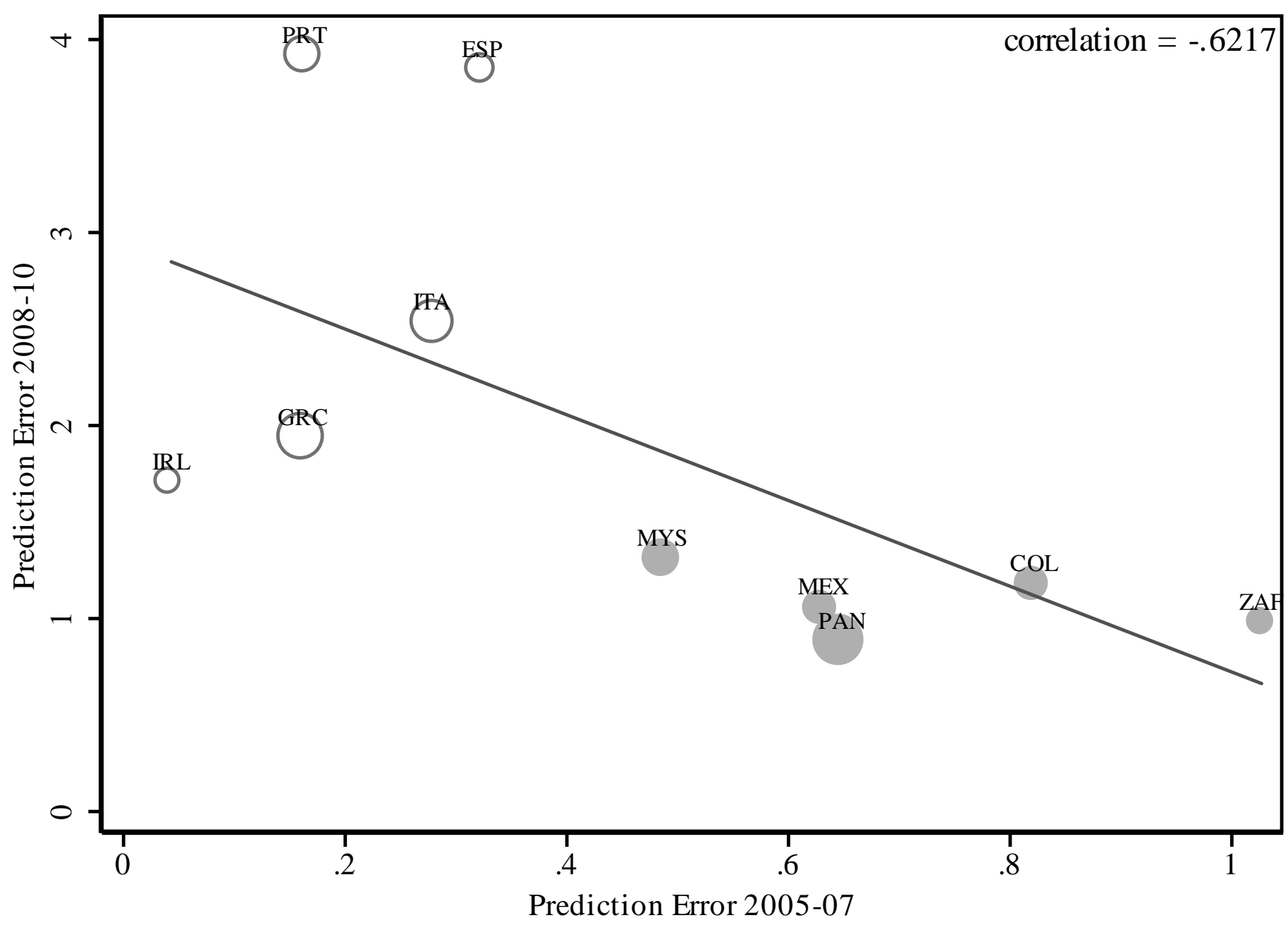

